Portland State University

PDXScholar

\title{
Selected experiences of boys and girls entering the community of Ketchikan, Alaska from correctional schools
}

Marian L. Swain

Portland State University

Follow this and additional works at: https://pdxscholar.library.pdx.edu/open_access_etds Let us know how access to this document benefits you.

\section{Recommended Citation}

Swain, Marian L., "Selected experiences of boys and girls entering the community of Ketchikan, Alaska from correctional schools" (1969). Dissertations and Theses. Paper 887.

https://doi.org/10.15760/etd.887

This Thesis is brought to you for free and open access. It has been accepted for inclusion in Dissertations and Theses by an authorized administrator of PDXScholar. Please contact us if we can make this document more accessible: pdxscholar@pdx.edu. 
AN ABSTRACT OF THE THESIS OE Marian L. Boatman Swain for the Master of Social Work presented April 15, 1969.

Title: Selected Experiences of Boys and Girls Entering the Community of Ketchikan, Alaska from Correctional Schools.

\section{APPROVED BY MEMBERS OF THE THESIS COMMITTEE:}

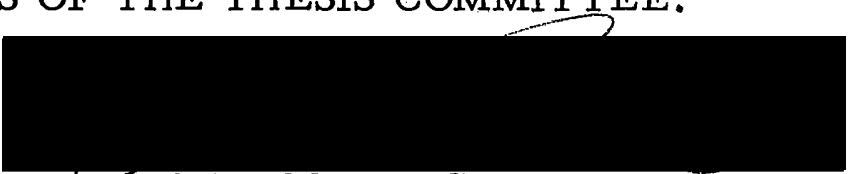

Frank F, Miles, Chairman

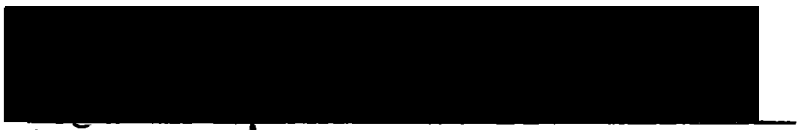

Wayne Suttles

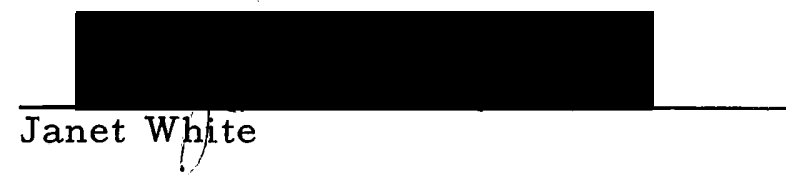

The purpose of this study was to explore differences in selfreported experiences of fifteen boys and girls who were released from correctional schools from June 24, 1965, to May 16, 1967, into the community of Ketchikan, Alaska, from a control group of nineteen who had not been in correctional institutions, who were matched by sex, age and race.

Between the dates of July 16, 1967, to September 13, 1967, I interviewed and administered a questionnaire to each respondent in 
both groups. The respondents, ranging in age from 14 years to 20 years, were seen in the welfare office, the person's home or foster home, the jail, other institutions and other settings.

The items that I chose for the questionnaire were those from the Seattle Atlantic Street Center's Student Opinion Survey with regard to the following six classifications:

1. Report of delinquent behavior.

2. Attitude toward community norms.

3. Delinquent friends.

4. Perception of community reaction to deviance.

5. Integration in neighborhood.

6. Activities and companions in activities.

The significance of the difference of the responses of the two groups was determined by the chi-square test of significance at the 5 per cent level of confidence. Because of the smallness of the two groups and because of the lack of random sampling in the selection of the second group, the findings could not be considered conclusions applicable to a larger population. However, generalizations as speculations to suggest further research and principles for action were made.

There were both similarities and differences in the two groups. The releasees admitted more misbehavior and knew young people in similar circumstances. Both groups were objective about friends, 
drank liquor (with different meaning and consequences), thought they were expected to finish high school, expected punishment for misbehavior and thought they had a chance of being caught for misbehavior by the police. The average or normal youngster had higher aspirations, expectations and attainment at school, work and play. The releasees participated more in unorganized activity and were more apt to be with the "gang" or "loners." 
SELECTED EXPERIENCES OF BOYS AND GIRLS ENTERING

THE COMMUNITY OF KETCHIKAN, ALASKA

FROM CORRECTIONAL SCHOOLS

by

MARIAN L. BOATMAN SWAIN

A thesis submitted in partial fulfillment of the requirements for the degree of

MASTER OF SOCIAL WORK

Portland State University

1969 
TO THE OFFICE OF GRADUATE STUDIES:

The members of the Committee approve the thesis of Marian L. Boatman Swain presented April 15, 1969.

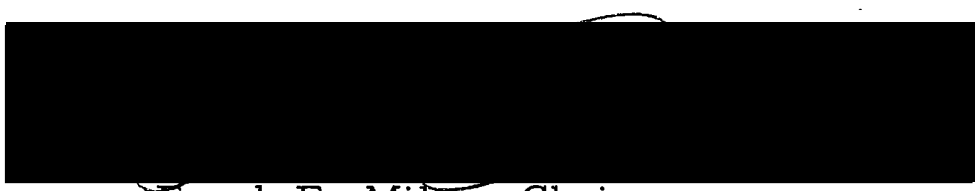

Frank F. Miles, Chairman

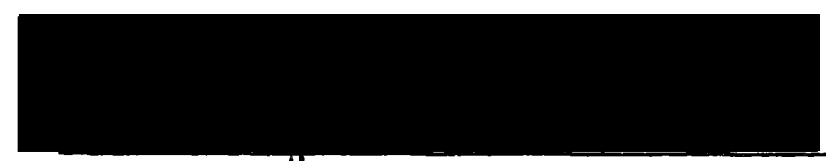

Wayne Suttles

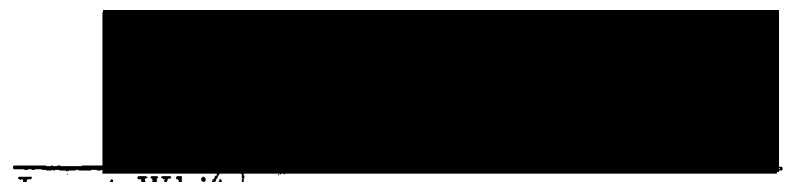

Janet White

\section{APPROVED:}

Daniel E. Jennịgs, Acting Dean, School of Social Work

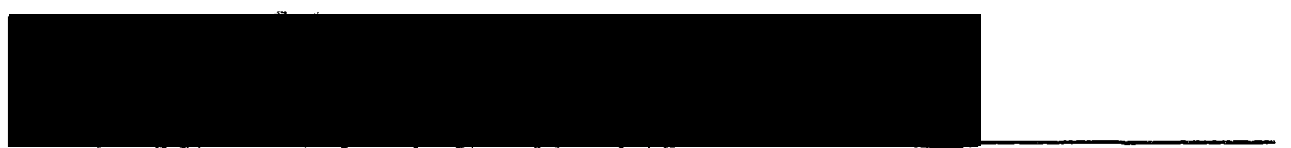

Datid R. Malcolm, Acting Dean of Graduate Studies

April 20, 1969 


\section{ACKNOW LEDGMENTS}

My deep appreciation goes to the people of Alaska who made this work possible - - especially to the young people who gave their time, interest and knowledge to provide the data, and to the Division of Corrections, which made the necessary records available.

I wish to express my appreciation to the faculty of Portland State University, especially Dean Gordon Hearn and Dr. Frank Miles, who understood my wish to be better prepared for social action research in my community; to Wayne Suttles for his helpful suggestions and to Miss Janet White and Mrs. Betsie DeBeer Smith for their careful editing of my manuscript.

Unbounded thanks to my dearfamily, particularly, my husband, Ted Swain, who died before the thesis was completed, our son Scott and my sister, Dr. Maleta J. Boatman, who gave me faith that I could complete the task. 
TABLE OF CONTENTS

PAGE

ACKNOW LEDGMENTS . . . . . . . . . . . . . .

LIST OF TABLES . . . . . . . . . . . . . . . vi

CHAPTER

I INTRODUCTION . . . . . . . . . . . 1

Statement of Problem . . . . . . . . . . . 1

Definition of Terms . . . . . . . . . 6

Development of Research Method . . . 7

II GEOGRAPHICAL AND HISTORICAL

BACKGROUND ............... . . 10

Geography . . . . . . . . . . . 10

History ............. . . 12

Patterns of Delinquency . . . . . . . 19

III UNDERLYING RESEARCH . . . . . . . 22

Studies of Alaska in Transition to

Statehood ............. 22

Studies in the State of Alaska . . . . . 24

Other Research Pertinent to Alaska . . 29

Research Underlying Method . . . . . 29 
Conclusions ..............

IV THE RESEARCH PROCESS ........

Research Design ..........

Pretest...............

Final Formulation of the Questionnaire.

The Young People of the Study Group and Control Group. . . . . . . . . .

Official Records . . . . . . . .

Interviews . . . . . . . . . . . . .

V THE FINDINGS ..............

Report of Delinquent Behavior .... . .

Attitude Toward Community Norms . .

Delinquent Friends . . . . . . . . .

Perception of Community Reaction to Deviance . . . . . . . . . . . . .

Integration in Neighborhood . . . . . .

Activities ............. .

Summary .............. .

VI CONCLUSIONS .............. 


\section{LIST OF TABLES}

TABLE

PAGE

I Questionnaire: Self-Report of Delinquent

Behavior...............

II Questionnaire: Attitude Toward Community

Norms ..............

III Questionnaire: Delinquent Friends . . . . . .

IV Questionnaire: Perception of Community

Reaction to Deviance ......... .

V Questionnaire: Integration in Neighborhood. .

Questionnaire: Activities .........

VII Offense Record: of the Members of the Study

and Control Groups, from Contact Slips

of the Ketchikan City Police Department,

on File in Youth and Adult Authority

Office ................

VIII Age of Respondents of Study and Control

$$
\text { Groups, July 13, } 1967 \text {. . . . . . . }
$$

IX Sex of Respondents of Study and Control

Groups ............... 
X Proportions of Identifiable Racial or

Linguistic Groups Represented by

Respondents . . . . . . . . . .

XI Frequency Distribution of School Grades

Completed by Members of Study and

Control Groups, July 13, 1967 . . . . .

XII Categories in Which the Responses of the Two

Groups About Self-Reported Delinquent

Behavior Were Not Significantly Different

XIII Categories in Which the Responses of the Two

Groups About Self-Reported Delinquent

Behavior Were Significantly Different . .

XIV Categories in Which the Significance of

the Difference of the Responses of the

Two Groups About Self-Reported

Behavior Could Not Be Determined. . .

XV Per Cent of Responses in Each Category

for Both Groups on Report of Delinquent

Behavior ............ .

XVI Categories in Which the Responses of the Two

Groups About Friends' Delinquent Be-

havior Were Not Significantly Different. . 
Categories in Which the Responses of the

Two Groups About Friends' Delinquent

Behavior Were Significantly Different . .

XVIII

Categories in the Group's' Self-Report and

the Groups' Report of Friends' Be-

havior in Which There Were No

Significant Differences . . . . . . .

XIX The Significance of the Difference in

Categories in Which the Groups' Self-

Report and the Groups' Report of

Friends' Behavior Could Not Be

Determined . . . . . . . . . .

Percentage of Responses of the Two Groups

with Regard to Perception of Community

Norms, Aspirations and Expectations of

Educational Achievement. . . . . .

XXI Categories in Which There Were Significant

Differences in the Responses of the

Control Group in Attitudes about

Community Norms of Educational

Achievement ............ 
XXII Categories in Which There Were Significant

Differences in Respect to the Number of Young People Each Group Knew Who

Had Been in Trouble.... . . . . . .

XXIII Percentage of Number of Responses about

Number of Young People Known Who

Had Been in Trouble or in Court. . . . . .

XXIV Categories in Which the Responses of the Two

Groups about Likelihood of Discovery of

Misbehavior were Not Significantly

Different . . . . . . . . . .

XXV Categories in Which the Significance of

Difference about Likelihood of Discovery

Could Not Be Determined . . . . . . . .

XXVI Percentage of Responses of the Two Groups

with Respect to Likelihood of Discovery

of Misbehavior. . . . . . . . . . .

XXVII Categories in Which the Responses of the Two

Groups about Likelihood of Punishment

Were Not Significantly Different. . . . . 
Percentage of Responses of the Two Groups with Respect to Likelihood of Punishment . . . . . . . . . . .

XXIX Percentage of Responses of Both Groups

about Integration in Neighborhood... .

XXX Percentage of Number of Responses about

Activities Engaged In. . . . . . .

XXXI Usual Companion at Various Activities

Shown in Percentage of Number.... 100

XXXII Usual Companion - Shown in Percentage of Number .............

XXXIII Categories in Which There Were No

Significant Differences in Participation

in Certain Activities . . . . . . . .

Differences in Participation in Certain Activities ............ 


\section{CHAPTER I}

\section{INTRODUCTION}

The aim of this study is to explore differences in self-reported experiences of the boys and girls who were released from correctional schools from June 24, 1965, to May 16, 1967, into the community of Ketchikan, Alaska, from a control group who had not been in correctional institutions.

\section{STATEMENT OF PROBLEM}

In the spring quarter of the academic year 1966-67 at Portland State College Graduate School of Social Work, I was a member of a

research group ${ }^{1}$ which reviewed the literature and discussed ways of doing research on institutionalized juvenile delinquents returned to their communities.

As an Alaskan since 1953 and as a child welfare worker in Ketchikan from 1956 to 1966, I realized that now would be a good time for the communities of this new State to foster some research

1 This group proceeded to complete the study: Thomas DeJardin et al., "The Assessment of Subjective Experiences of Boys Entering the Community from a Correctional School" (unpublished Master's thesis, School of Social Work, Portland State College, 1968). 
about what was happening to their young people in trouble. The social structure was changing so rapidly that it was affecting young people's behavior. Because of the small sizè of the population and the multiple natural physical boundaries within the area, the processes of change were visible and potential study samples were readily identifiable.

This change was occurring rapidly in two major ways. First, Alaska was moving from a rural wilderness inhabited by natives, adventurers and pioneers to a more urban-centered frontier with a preponderantly middle-class population which was expanding. The mixture of peoples created confrontation of cultures within a shifting economic system. Second, the advent of statehood on January 3 , 1959, initiated a reorganization of government from that of a colonial territory to that of an independent state. Some of the processes involved in these changes inevitably affected the nature of deviant behavior as well as the laws concerning the apprehension, treatment and control of delinquents.

Ketchikan, as well as the rest of Alaska, continued to undergo many physical, economic and social changes due to heavy immigration from the rest of the United States since the 1940's. One result in the early 1950 's was a new town administration which decided to control juvenile delinquency. This resulted in the building of a detention home in Ketchikan in 1957, the first ever built in an 
Alaskan town.

With Statehood, the State Youth and Adult Authority became the agency which had jurisdiction over all juvenile programs in the field of corrections, including this detention home. Institutions in Washington, California, Colorado and Montana continued to provide care by contract for some boys and girls whom the State Juvenile Court occasionally committed to the Alaska Youth and Adult Authority for care, custody and treatment. In addition, this Authority used the Alcantra Youth Conservation Camp and School opened June 19, 1960, at Wasilla, Alaska. The name of the Authority was changed to the Division of Corrections, October 1, 1968.

In the early 1960's Alaska State agencies began planning the building of a large residential juvenile diagnostic and treatment center in Anchorage. This McLaughlin Center was to open in the summer of 1968 as Alaska's first major effort in full-scale treatment of youth in an institutional setting. Throughout the planning period there were differing points of view about how progressive a step this was to be.

Some people thought of this proposed center as "the initiation of an institutional treatment program so advanced in some areas that it could well serve as a pilot for similar programs throughout 
the country. "1 The development of this institution to serve a particular population reflected awareness of the inadequacy of sending young people to other states far from home to communities very different from their own. Mr. Lauber, Director of the Youth and Adult Authority and Juvenile Judge in Ketchikan, 1960-1967, said:

Say we send a youngster to the federal institution in Englewood, Colorado, for youthful boy offenders. He has a roommate there from New York, Los Angeles or Chicago. After nine months or a year in the institution the boy from one of these other areas goes home and he knows how to carve ivory and our youngster comes home and he knows how to smoke marijuana. We don't consider this to be a fair trade.

Alaska's small population both necessitated economically and made feasible size-wise one centralized institution. Location in Anchorage had advantages because of the concomitant development of psychiatric treatment facilities there. The combination could made a modern treatment center.

Other leaders in the field of delinquency felt that the best way to handle most juvenile delinquents was by working with them in their own community. ${ }^{3}$ The trend in the United States is to provide community services not only to small but also to local populations.

${ }^{1}$ Alaska, Department of Health and Welfare, Alaska's Health and Welfare, Vol. 24 (June, 1967), p. 15.

${ }^{2}$ Alaska Reporting Service, Report No. 324, Department of Health and Welfare, Juneau, Alaska, June 26, 1967, p. 8.

3 Ibid. , p. 9. 
For areas far from Anchorage, like Ketchikan, the transportation problems and the environmental differences might outweigh the advantages of planning treatment in a centralized facility.

These factors emphasized the need for evaluative research as an integral part of Mc Laughlin Center's program. If the best use were to be made of the Center, local communities would need to be thoughtful in the development of their own programs. The latter would be particularly true if there were validity to the increasingly held point of view that delinquent behavior is a function of the environment as well as of the individual. 1

Having already begun with a group of graduate social work students to plan research on institutionalized delinquents, it seemed timely for me to proceed with a project in Alaska. I began with the premise, already in use by a number of social agencies, that nonconforming behavior is rational behavior. By rational behavior is meant that behavior, given the environmental and social context in which it appears is "normal behavior. "2 I as sumed that if young people treated in social agencies were to behave in a manner

${ }^{1}$ Ellingston, John R., "Youth Authority Plan and Its Development in California," California Youth Authority Quarterly, Vol. 20 (Fall, 1967), p. 29, quoting the President's Commission of 1965. Beck, Betram M., "Innovations in Combating Juvenile Delinquency," Children, Vol. 21 (March-April, 1965), p. 70.

${ }^{2}$ Seattle Atlantic Street Center, Second Year Progress Report, "Introduction and Orientation to the Service," June, 1964, p. 4. 
acceptable to their community, they would need an environment and social context similar to that of young people of adjudged desirable behavior. It would be important then in understanding the local community's part in rehabilitation to know whether delinquents returning from an institution have the same experiences as comparable non-delinquents. One way of exploring this would be to compare self-reports of two such groups.

\section{DEFINITION OF TERMS}

For the purpose of this study Webster's definition of experience is used: "The actual living through an event or events; actual enjoyment or suffering; hence, the effect upon the judgment or feelings produced by personal and direct impressions. "1

The term correctional school or institution is used as a generic term which includes camps, juvenile training schools or reformatories, as defined by the National Council on Crime and Delinquency. I chose to use the Council's definition of the correctional school's role as follows:

A juvenile training school's role is to provide a specialized program for children who must be held to be treated. Accordingly, such facilities should normally house more hardened or unstable youngsters than should be placed, for example, under probation facilities. . .

${ }^{1}$ Webster's New Collegiate Dictionary (Springfield, Mass: G. and C. Merriam Co., Publishers, 1961), p. 291. 
The juvenile institutional program is basically a preparation and trial period for the ultimate test of returning to community life. Once return has been effected, the ultimate success of the facility's efforts is highly dependent on good aftercare services. These are needed to strengthen changes started in the institution; their value can be proved only in the normal conditions of community life. ${ }^{1}$

The detention home's function is to provide care for children of juvenile court age in secure custody for court disposition, 2 and is to be distinguished from the term correctional school, the function of which is to provide treatment after the court disposition of commitment.

\section{DEVELOPMENT OF RESEARCH METHOD}

As the experimental or study group of 15 members for this research project I selected all the boys and girls available for interviewing who had been in correctional schools on commitments from the State Juvenile Court at Ketchikan or on commitments from courts in other states, ${ }^{3}$ and who were released into the community

1"A Survey for the President's Commission on Law Enforcement and Administration of Justice", Crime and Delinquency, Vol. 13 (New York: National Council on Crime and Delinquency, Jan. , 1967), p. 185 and p. 73.

2

Ibid. , p. 11 .

${ }^{3}$ Under Interstate Probation-Parole Compacts Alaska's Division of Corrections supervises probationers from other states, and Alaska's probationers are supervised in other states by those states' correctional departments. This compact is called the Uniform Reciprocal Agreement. 
of Ketchikan between set dates. These dates covered the latter part of the transition in the care of delinquents by Alaska as a territory, to Alaska as a state. More detail about the pertinent geographical and historical background is given in Chapter II.

I matched the experimental group with a control group of 19 members of boys and girls of similar age, sex and ethnic background, from the same community, who had not been in any correctional institutions.

Each member of both groups responded to a questionnaire I gave them individually and in person. The items that I chose for the questionnaire were those from the Seattle Atlantic Street Center's Student Opinion Survey ${ }^{1}$ which had drawn responses that raised questions about the nature of deviance and social control. This and other underlying research is reviewed in Chapter III. In Chapter IV the method of carrying out my research project is detailed.

The point at issue in this research project was the significance of the difference in the questionnaire responses by the two groups with regard to their reports of experience in the following six clas sifications:

${ }^{1}$ Leroy C. Gould, "The Student Opinion Survey: Analysis and Discussion," The Effectiveness of Social Work with Acting-Out Youth, Fourth Year Progress Report, September, 1965-August, 1966, Seattle Atlantic Street Center (Seattle: Seattle Atlantic Street Center, Sept., 1966) pp. 1-64. (processed). 
1. Report of delinquent behavior.

2. Attitude toward community norms.

3. Delinquent friends.

4. Perception of community reaction to deviance.

5. Integration in neighborhood.

6. Activities and companions in activities.

The test of significance was the chi-square. The degree of confidence was at the 5 per cent level.

The findings described in Chapter $\mathrm{V}$ indicate that there were some differences in the subjective reports of the two groups and that the delinquency of this study group was partly a function of the community as well as the individual. In Chapter VI this and some implications for future research and practice are discussed. 


\section{CHAPTER II}

\section{GEOGRAPHICAL AND HISTORICAL BACKGROUND}

Some knowledge of the geographical setting and the general historical background of Southeastern Alaska will help in understanding not only the research findings that will be mentioned in the next chapter, but also my research process, the individuals of my two sample groups and my findings.

\section{GEOGRAPHY}

\section{Ala ska}

Alaska, the 49 th and largest of the states of the United States of America, covers an area of 586,400 square miles. It has the smallest population of any state, 271, 505 estimated July 1, 1966, less than that of the city of Portland, Oregon. ${ }^{1}$ The climate ranges from Arctic temperatures in the north to a temperate zone of heavy rainfall along the coast. The pattern of long summer days and long winter nights exists in varying degrees, in all parts. There is a

${ }^{1} \mathrm{~J}$. Scott McDonald, Alaska. State Plan for Construction of Mental Health Centers (Juneau, Alaska: Department of Health and Welfare, 1968), p. 46. 
three hour time difference from one end of the state to the other. For thousands of years Alaska has been the home of three distinct racial groups, the Eskimos in the north, the Aleuts in the Aleutian Chain, and the Indians, both the Interior and the Coastal groups.

Southeast Alaska and Ketchikan Area

Alaska has 26,000 to 28,000 miles of shoreline, more than all of the rest of the United States combined. Much of this is due to the Alexander Archipelago, the thousand islands which stretch southeastward from mainland Alaska in a "panhandle" formation off the western coast of Canada. The town of Ketchikan clings on the steep, fjordcut northwest coast of Revillagegido, one of the most southern of these islands.

Ketchikan, the area chosen for the Research Project, has quite a diffe rent setting from that of the city slum usually associated with delinquency. Ketchikan is the first port of call in Alaska for ships coming from the south. Its only access is by water via boat or seaplane. It is the shopping, Coast Guard and professional service center for the sparse villages and logging camps in an area spanning 100 airmiles of low mountain wilderness rising out of deep, sheltered coastal waterways. The year round heavy rainfall averages 150 inches per year, which, combined with the warmth from the Japanese ocean currents, produces luxuriant rain forests 
and lush undergrowth, including myriads of berries. The area is the spawning ground of salmon and herring. There is an abundance of many other kinds of animal life.

Inside Ketchikan's city limits are 8, 039 people, and in its service area are $13,039 .^{1}$ The immediate vicinity is the Gateway Borough of which Ketchikan is a part. The Gateway Borough consists of 1, 280 square miles on Revillagegido Island, and Gravina and Pennock Islands, which lie across the channel. The population consists of three linguistic groups of Indians, the settlers and their descendants, new capital investors, the middle class, the Coast Guard enlisted men and dependents, the seasonal workers who come to. log, fish and can, and the tourists.

\section{HISTORY}

The area of which Ketchikan is the center has been particularly subject to interaction between cultural groups both before and since Alaska's discovery by Vitus Bering in 1741 . The most obvious conflict, after the United. States purchased Alaska from Russia in 1867 , has been reflected in the dual system of economic and social relations between the native peoples and the white settlers.

${ }^{1}$ Ketchikan Chamber of Commerce Office, Interview with Mrs. Celeste Gerde, September 9, 1968. 
Indigenous Population

In Southeastern Alaska reside Indians descended from three major linguistic groups: The Tsimshian at Metlakatla on Annette Island; the Haida at Hydaburg and Kasaan, on Prince of Wales Island; and the Tlingit, in the Henya Tlingit village of Klawock on Prince of Wales:Island and in the Cape Fox Tlingit and Tongass Tlingit village of Saxman on Revillagegido Island.

Southeastern Alaska originally was the home of the Tlingit. The Haida, "people of the straits, "l were descended from a group , living immediately to the south on the Queen Charlotte Islands, who had crossed Dixon's Entrance over 200 years ago. They made war on the Tlingit and won the southern part of Prince of Wales Island. 2 Contact with the Tsimshian probably occurred near the Nass or Skeena Rivers until the advent of the missionaries, when Father Duncan brought 825 members of the Gitlan tribe to Metlakatla on Annette Island, from British Columbia in August, 1887. Reverend William Duncan was an Anglican missionary who had broken with his superiors of the Church of England in British Columbia and had

${ }^{1}$ Joseph Wherry, The Totem Pole Indians (New York: William Funk, Inc., 1964), p. 15.

2 Edward L. Keithahn, Monuments in Cedar (Ketchikan: Roy Anderson, 1945), p. 27. 
secured permission from Congress to bring his flock of Tsimshian Indians to Alaska. 1

These three linguistic groups, the Tlingit, the Haida and the Tsimshian, had attained a high level of culture. Because of their pattern of rich summer harvesting and winter leisure the re was time to devote to the cultivation of artistic skills and the formation of a complex social organization. The linguistic groups were more alike than different in their economic, social and value systems as was reflected in their rules of conduct, their religious beliefs, their ceremonies and their arts and crafts. They had a matrilineal type organization but they did not disregard paternal rights and relationships. There was variation of organization among the three groups but the societies were all built up around "lineages, "the basic unit. 2 Each lineage retained its own economic possessions and operated as an independent unit. Each person had his own social position and rules of conduct defined according to status, from high to low, from chief to slave, obtained from heredity and from one's own actions. To be insulted or degraded individually was an insult to one's family. One existed only as a member of a lineage or family group.

${ }^{1}$ Ernest Gruening, The State of Alaska (New York: Random House, 1954), p. 61. Viola E. Garfield, Paul S. Wingert, and Marius Barbeau, The Tsimshian: Their Arts and Music (New York: J. J.. Augustin Publisher), p. 9.

${ }^{2}$ Phillip Drucker, Indians of the Northwest Coast (New York: The National History Press, 1955), p. 108. 
$\underline{\text { Settlement }}$

The explorers and traders were the first of the trek of people coming and going. These first white men with their wealth and with their different weapons, tools, diseases and liquor inevitably began altering the way of life of the Indian.

In 1886, the first cannery was built near Ketchikan Creek, a fi shing camp of the Tlingit. ${ }^{1}$ After 1896, Ketchikan was a supply station for boats going north to the gold fields. Following the stampede of miners, the town relied again on its fishing which was the base of its economy for another quarter of a century. The majority of the first settlers were blonde Scandinavian.

By 1920 the native people were the minority of the population. Although they maintained their several identities as separate familial and linguistic groups, they began to be seen and treated by the white majority as one group of "natives."

Segregation was the way of behavior both by written and unwritten law. One significant example was the discriminatory and confusing liquor laws. In 1867 the only law that Congress passed relating to Alaska, other than to appropriate money for its purchase from Russia, was to create a customs district. It prohibited the importation and sale of distilled liquors. In 1873 , this act was

${ }^{1}$ Mary G. Balcom, Ghost Towns of Alaska (Chicago: Adams Press, 1965), p. 37. 
amended to forbid the sale of liquor to Indians. ${ }^{1}$ However, sugar and molasses for "hoochenoo" were sent into Alaska from the beginning.

$\underline{\text { Recent History }}$

As in the rest of the United States World War II caused an upheaval of population. Many Russian-Aleuts, Eskimos, sailors and soldiers uprooted by the war, later made Ketchikan their home. Some of the newcomers did not take the segregation so much for granted and equal treatment laws were passed.

World War II also initiated a new age of transportation with the advent of amphibious planes. Increased use of aircraft all over Alaska abetted its settlement and its industry.

Coincidentally with the decrease of fishing due to years of exploitation, the logging industry increased with the building of the Ketchikan Pulp Company in 1954. ${ }^{3}$ This provided year-round employment and stabilized Ketchikan's economy. At the same time, with the decrease in fishing, some of the Indian villages were dying.

${ }^{1}$ Ernest Gruening, citing 40C: 2s, Sen. 619 and $43 \mathrm{C}: 1 \mathrm{~s}$, Ex. Doc. 71, p. 35.

2 "Hoochenoo" was the word used meaning home-made alcoholic beverage.

${ }^{3}$ Ketchikan Pulp Company Advertising Brochure, "The Story of Wood Pulp Manufacture in Southeastern Alaska,"pp. 2-3. 
The preceding description was not intended to be comprehensive. It describes some of the natural features and patterns of relationships that probably continue, to have an influence on the life in the area from which the research samples were drawn.

\section{Import of Geography and History}

The preceding discussion was included because I draw the following inferences as to the effect of climate and history on behavior today. Inhabitants in the area are constantly influenced by the natural factors which contribute to a feeling of confinement and restriction. The year round presence of overhanding clouds against the mountains not only keeps the area damp and dreary, but delays travel and adds to feelings of claustrophobia. Not only is there no unbroken expanse of land or water; there is limited visibility for days on end. The long winter evenings reinforce feelings of depression.

Perhaps the isolation makes things that are rhythmical like the coming of the salmon seem magical. When the days are long and the seasonal activity is at its peak, young people find it difficult to keep up with the routine expected of them in our society. When the weather is nice the young people explore the wilderness that is tantalizingly close. They use this same wilderness to run away in but eventually are driven out by the discomforts of dampness, cold 
and hunger.

The present economy based on fishing and logging continues the centuries old Indian pattern of summer activity and winter leisure. For some, however, the winter months today are more apt to be periods of boredom and discouragement than when the culture encouraged cultivation of artistic and social activities.

The movement of Indians from their dying villages to the town is difficult for the entire family. They live a portion of their lives in the security of their kinship group with familiar mores. In town as a minority group, they are suddenly expected to conform to more rigid standards of promptness, cleanliness, accountability of whereabouts and law.

For the native people, who consider status in relation to every family and community member important, to be indiscriminately treated as a member of a scorned minority group is difficult.

The middle-class families' transferring from metropolitan areas in other states find the change difficult, especially for the women. Such moves away from extended families have similarities to pioneering because of the distance, the difficulties of transportation and the change in the nature of dangers encountered.

There is no anonymity in the villages or in Ketchikan, or in traveling from one place to another. Plane and boat travel in Alaska is like "walking down main street." The visibility is difficult for 
the person from heavily populated areas and also makes any deviance unusually noticeable.

Throughout the history of this area, young people have had to deal with transition and shifts in values and meanings, all sources of confusion and conflicts. Certainly, during the last 20 years the problems of learning have been tremendous for both the native and the non-native populations, and there have been deep misunderstandings. Not only were the values, mores and societal characteristics of the natives challenged, but also the values, mores and societal characteristics of the non-natives.

\section{PATTERNS OF DELINQUENCY}

This section on officially recorded delinquency is included to complete the background history.

In 1966 the Ketchikan police arrested 268 young people under 18, 135. Caucasian, 128 Alaska natives and 6 others. The highest number of offenses were curfew violation, loitering, breaking the liquor laws, larceny, theft, drunkenness and disorderly conduct. The police referred 60.2 per cent of the young to the Youth and Adult Authority Office, and handled 39.8 per cent within the department 
with a warning to the young person or to his parent. ${ }^{l}$ The arrests of this group under 18 comprised 23 per cent of the total arrests. The increase over 1965 was about 2 per cent. ${ }^{2}$ It was close to the 1955 number of 216. The Ketchikan Police Department counted its caseload as 14 in 1949, 15 in 1950, 103 in 1953, 195 in 1954, and the 216 in $1955 .^{3}$ The increase since 1949 was due in part to an added emphasis on enforcement and to a change in record keeping.

The adult offenses were similar, except for curfew violation which is not an adult offense. In addition to the offenses listed above, adults of age 21 and over and young adults between the ages of 18 and 21 were charged with furnishing liquor to a minor, driving while under the influence of alcohol, young adult in possession of liquor, minor (young adult) consuming liquor and as sault and battery. 4

With this sketch of the country and its history in mind,

${ }^{1}$ For an overlapping period, not exactly comparable in time, the Ketchikan State Detention Home showed that of the number of juveniles detained over 60 per cent were Alaska natives. This would seem to indicate that the community made it possible for the police to handle a higher proportion of Caucasians without detention.

2 Ray Hackstock, Ketchikan Police Department, copy of reports of 1965 and 1966 for FBI Uniform Crime Reporting.

${ }^{3}$ U.S. Congress, Senate Subcommittee, Juvenile Delinquency in the Territory of Alaska, 84th Congress, 2nd Session, 1956, Senate Report Number 2774, p. 7.

${ }^{4}$ Ray Hackstock, op. cit. 
Chapter III has more meaning. It includes a review of previous research that has been done on delinquency in Alaska as well as a review of other research in preparation for this project. 
CHAPTER III

\section{UNDERLYING RESEARCH}

The emphasis in this chapter is on Alaska research because this is the community into which the respondents of the present research project were released.

\section{STUDIES OF ALASKA IN TRANSITION TO STATEHOOD}

As described in the history of Alaska, ${ }^{l}$ the period following World War II and surrounding the advent of Statehood was filled with new interest and emphasis on law, order and fairness. During this transition period at least three investigative studies were initiated by law makers in preparation for changes in laws and appropriations. In 1956, a Senate subcommittee incorporated these in their Senate Report. $^{2}$

First, a study of juvenile delinquency in Alaska was conducted from 1953 through 1955 by a legislative council, a permanent committee established by the Alaska Territorial Legislature of 1953.

${ }^{1}$ Chapter II, p. 16.

${ }^{2}$ U. S., Congress, Senate Subcommittee, op. cit. 
Informative and opinion-gathering hearings were undertaken through the Territory. The juvenile code then as now, specifically prohibited detention of youth in jails, unless they could be separated from adult prisoners. The need for suitable detention homes for young people was stressed by the residents of major cities. Following this investigation, the legislative council drafted a bill, enacted by the 1955 legislature, to provide a system of detention homes. The bill provided for a board of juvenile institutions composed of five members appointed by the governor. ${ }^{1}$

Second, William G. Long, Judge of the Superior Court, King County, State of Washington, at the request of the legislative council, went to Alaska in 1954 to study the juvenile problem by interviewing people and holding hearings. He wrote that he found no facilities or personnel for the care, treatment or rehabilitation of delinquent youth. 2

Third, in 1955, at the request of the Alaska public officials, a subcommittee of the Committee of the Judiciary of Congress, 3 investigated the problem of juvenile delinquency in the Territory by interviewing public officials. The subcommittee learned that Alaska had had a juvenile code since 1943 ; that the commissioners' courts, i. e., the lower courts of the Territory, had juvenile jurisdiction;

Ibid., p. 1. ${ }^{2}$ Ibid., p. 7. ${ }^{3}$ Ibid. 
that the Territorial Department of Public Welfare gave service to the commissioners' courts; and that the method had worked fairly well until the population growth of Alaska in the 1950's. The fol:lowing quotation indicates that the treatment of children in the only available correctional institutions, those in mainland areas, had not been effecting. "cures". 1 The United States marshal from Anchorage said:

Now, to incarcerate a child, even for his own good, to uproot him and transport him vast distances is the very antithesis of cure. Not only does it isolate the child and force him to retreat further into rejection and antisocial patterns, but it places an added and unnecessary burden on all agencies involved. Surely the existence of delinquency homes in this division would alleviate this dismal procedure.

\section{STUDIES IN THE STATE OF ALASKA}

In the early 1960's agencies in the State sponsored some research and assessed Alaska's needs as part of comprehensive social planning.

In the summer of 1.962, the Department of Health and Welfare and the University of Alaska made an exploratory, impressionistic study of the northwest section of the state, called the Nome Study. The researchers observed conditions and activities and conducted

\footnotetext{
${ }^{1}$ Chapter I, p. 3

${ }^{2}$ U. S., Congress, Senate Subcommittee, op. cit., p. 9.
} 
interviews. The most frequent offenses were drinking, petty thievery, vandalism and sexual promiscuity. 1

During the 1965-66 academic year, Jan Tillotson and Dennis Eleasser at Alaska Methodist University presented data in the form of hypothesized associations between juvenile delinquency and characteristics. ${ }^{2}$ Traits of race, socio-economic level of the family, previous criminal involvement of one or more of the family members, the absence of one or both natural parents and working mothers were selected. Tillotson and Eleasser used a sample which encompassed 411 Youth and Adult Authority juvenile case files of youths residing in the Anchorage area. The sample included all current, open cases and a random sample of cases closed within the preceding six years. The statistical probability of each hypothesis was determined by the use of the chi-square formula. One finding was that race is a significant "factor" in juvenile delinquency in Anchorage. The 1960 Census Data revealed that $71 / 2$ per cent of the Anchorage population were non-white which did not correspond to the percentage of non-white in the sample. However, the comment

\section{${ }^{1}$ Alaska, Department of Health and Welfare, Alaska's Health} and Welfare, Vol. 19 (October, 1962), pp. 4-5.

2 Jan Tillotson and Dennis Eleasser, "Juvenile Delinquency: A Study" (unpublished. Alaska Methodist University. February 2, 1966 - August 5, 1966). 
was made that other factors such as socio-economic status, selective non-white arrests, greater control over non-white areas, and less severity in regard to white offenders would need to be considered. ${ }^{1}$

In 1964, Daniel Blain, President, American Psychiatric Association, was consultant to the State Division of Mental Health and the Alaska Governor's Planning. Committee on Mental Health and Mental Retardation. ${ }^{2}$ Although he assumed that the incidence and characteristics of mental disorders and retardation were not greatly different from that found in other states, he stated facts that throw some light on the subject of my study:

There is a continual reference to the clash between the native Eskimo, Indian or Aleut, and the white intruder. Some suggest they are better off left alone; others, we should "civilize" them as quickly as possible. The fact is that while civilization has intruded--with good and bad effects. . . there is no turning back . . . The conditions produce anxiety, . . problems of learning and communication, language and poor comprehension. Most likely they produce social maladjustments resulting in alcoholism, accidents, homicide, delinquency, dependency. ${ }^{3}$

The Comprehensive Mental Health Report ${ }^{4}$ described the

1 Ibid.

2 Daniel Blain, Alaska Survey, Mental Health and Mental Retardation, State of Alaska (Department of Health and Welfare, Division of Mental Health, September, 1964).

3 3 Ibid., p. 49.

${ }^{4}$ Barbara Ure, Comprehensive Mental Health Planning, 1963 64, State of Alaska (Governor's Committee, July, 1965). 
change in Alaska over time and over space, with comparisons of communities throughout the State, and comparisons of the entire State with other areas. It was a description of the struggles of the community groups' collecting statistics, evaluating what they might mean and recommending what seemed best for its community. The greatest need felt for the state was manpower and planning services in local communities.

Barbara Ure, child psychiatrist for the State Department of Mental Health in the early 1960's, found alcoholism the major social and health problem that had not been dealt with adequately; crimes of violence, suicides, accidents, divorce, and other indices of social disequilibrium were also high; the disparity between the native and Caucasian economic structure and culture amplified the problems. The committee ranked as first priority for the State a community mental health center for Ketchikan. The reason for this priority was that Ketchikan had no existing mental health services. All of the embryonic services in the State were too far distant to be of help to this area. Barbara Ure stated in regard to minors in particular:

It should be noted that juvenile delinquents in Alaska are relatively unsophisticated and more typical of rural areas than in many other states. The practice of sending juvenile 
delinquents to California is to be deplored since Alaska's delinquents are really "babes in the woods" compared with the "hardened toughs" of the city. "

The Western Interstate Commission for Higher Education sent a Traveling Team to Alaska in the summer of $1963 .^{2}$ The primary focus of the team was to provide "stimulation through seminars, consultations, and informal meetings." Recommendations were made to support the Alaska Youth and Adult Authority staff in its long-range planning.

1. Physical facilities for detention of juveniles should be improved. . . Unless something drastic is done to improve the over-all personnel there will be much disappointment throughout the state.

2. The detention facilities in both Juneau and Ketchikan are so poor that their use should be terminated. As a rule personnel needs are paramount and physical facilities are secondary. However, these facilities are so poor that the physical structures get in the way of any good program for rehabilitation.

3. There is a great need for an over-all, coordinated program of rehabilitation for juveniles.

a. The various agencies involved with rehabilitation programs need to plan together and to share thinking, facilities and central records.

I Ibid., p. 117.

${ }^{2}$ Samuel Haig Jameson and Dorothy Sherman, A Report on the Alaska Traveling Team, ed., William T. Adams (Boulder, Colorado: Western Interstate Commission for Higher Education, 1964) 
b. An over-all program of rehabilitation and prevention that is clearly identifiable as State policy should be at the level of awareness for all professional personnel.

\section{OTHER RESEARCH PERTINENT TO ALASKA}

In his study of Canadian parole applicants Francis Reilly focused on the areas of family relationships, work, criminal behavior and efforts toward rehabilitation. His conclusions were that the Indian group was asocial whereas the non-Indian group was antisocial, and therefore, social work treatment should be at the "grass-roots" level for the Indians, aimed at building controls in both the Indian offender and his milieu. The non-Indian offender seemed better geared to using present treatment techniques. 2

\section{RESEARCH UNDERLYING METHOD}

A review of the Atlantic Street Study ${ }^{3}$ is included because it underlies my Ketchikan study and the method I used. The Seattle

${ }^{1}$ Ibid., pp. 6-7.

2 Francis J. Reilly, "A Comparative Study of Indian and NonIndian Parole Applicants in Alberta" (unpublished Master's thesis, St. Patrick's College, Ottawa, Ontario, 1967).

${ }^{3}$ Seattle Atlantic Street Center, Effectiveness of Social Work with Acting-Out Youth: Second Year Progress Report, September, 1963 - August, 1964 (Seattle: 1964). (Processed).

Seattle Atlantic Street Center, Effectiveness of Social Work 
Atlantic Street Center, a settlement in Seattle's marginal area, undertook to evaluate its social work services to boys. The evaluation is a delinquency prevention study in the tradition of the Cambridge-Sommerville Youth Study of thirty years ago. ${ }^{1}$ With the aid of a National Institute of Mental Health grant, the Center began its five-year study. The first year, 1962-63 was given to preplanning and the hiring of personnel; the second year, 1963-64, to a pretest phase in which selection procedures, social work services, recording instruments, and evaluative techniques were put into operation and refined. The test proper was conducted from 1964 to 1967 .

The project planned to work only with those boys in the population who had a high risk of eventually becoming delinquent. Selection of high-risk youth was determined by evaluation of school, police and juvenile court records, and by interviews with the child himself. The Student Opinion Survey was one of the indices utilized. The staff of the Seattle Atlantic Street Center administered with Acting-Out Youth: Third Year Progress Report, September, 1964 - August, 1964 (Seattle: 1965). (Processed).

Seattle Atlantic Street Center, Effectiveness of Social Work with Acting-Out Youth: Fourth Year Progress Report, September, 1965 - August, 1966 (Seattle: 1966). (Processed).

${ }^{1}$ Edwin Powers and Helen Witmer, An Experiment in the Prevention of Delinquency: The Cambridge-Sommerville Youth Study (New York: Columbia University Press, 1951). 
the Student Opinion Survey to 374 boys in the seventh grade in Washington and Meany Junior High Schools, Seattle, Washington, in April, 1964. ${ }^{1}$

The staff chose five theories of delinquency for formulating their hypotheses to test in its study: (1) anomie theory, (2) differential association theory, (3) community disorganization theory, (4) family disorganization theory and (5) self-concept theory.

Durkheim's anomie theory has as a starting point this proposition as restated by Robert Merton: "The more opportunity a person sees his society offer him to achieve his goals, the less likely that person is to deviate from the norms of that society. 12

Sutherland's differential association theory was summarized as: "The more of certain kinds of contact one has with other delinquents, the greater are his chances of exhibiting delinquent behavior. ${ }^{3}$

${ }^{1}$ Seattle Atlantic Street Center, Fourth Year Progress Report, op. cit., Leroy C. Gould, "The Student Opinion Survey: Analysis and Discussion, p. 1 .

2 Second Year Progress Report, op. cit., "A Theoretical Rationale," p. 2, citing Emile Durkheim, Suicide, A Study in Sociology, George Simpson ed., trans. John S. Spaulding. (Glencoe: The Free Press, 1951). Robert Merton, Social Theory and Social Structure (Glencoe: The Free Press, 1957). Richard Cloward and Lloyd Ohlin, Delinquency and Opportunity: A Theory of Delinquent Gangs (Glencoe: The Free Press, 1960). Albert Cohen, Delinquent Boys: The Culture of the Gang (Glencoe: The Free Press, 1957).

${ }^{3}$ Ibid., p. 3, citing Edwin H. Sutherland, Principles of Criminology (Philadelphia: Lippincott, 1947). 
The community disorganization theory of Shaw and McKay was

looked at from the point of view of the children themselves:

The more strongly one is integrated into the community, the less likely he is to deviate from the norms of the community.

The more one expects his community to apply negative sanctions for normative violations, the less likely he is to violate the community norms. 1

Two of the three propositions the Center Study adapted from family disorganization theory are quoted here:

The less adequate one's discipline as a child (excessively severe, absent, or partial) the more likely the person is to exhibit deviant behavior.

The greater cohesion of a family, the less likely are the children of that family to escape to deviant behavior. ${ }^{2}$

The fifth and last theory used was the self-concept theory as propounded by Walter Reckless: "The more one conceives. . . himself as a delinquent the more likely he is to engage in deviant behavior. ${ }^{3}$

I Ibid., citing. Clifford Shaw and Henry D. McKay, Juvenile Delinquency and Urban Areas (Chicago: University of Chicago Press, 1942), and Frederick M. Thrasher, The Gang (Chicago: University of Chicago Press, 1947).

2

Ibid., p. 4-5, citing. Sheldon and Eleanor Glueck, Delinquents in the Making (New York: Harper and Brothers, 1952), and F. Ivan Nye, Family Relationships and Juvenile Delinquency (New York: Wiley and Sons, 1958).

${ }^{3}$ Ibid., citing Frank R. Scarpitti, Ellen Murray, Simon Dinitz and Walter C. Reckless, "The 'Good' Boy in a High Delinquency Area," American Sociological Review, Vol. 25 (August, 1960), pp. 555-8. 
One of the questions that guided the formulation of the Student Opinion Survey by the Seattle Atlantic Street Center staff was this: Were the theories of delinquent behavior that helped guide the project really valid, especially in the particular community served by the Center?

The findings from the Student Opinion Survey were:

1. There was more troublesome behavior, self-reported, than was officially recorded. The inference was that self-reported behavior occurred; officially recorded behavior measured the incidence of the behavior which occurred that concerned the community.

2. There was a weak negative relationship between educational aspirations and officially reported delinquent behavior; and a stronger negative relationship between educational anticipations and officially reported delinquent behavior. The inference was that once a boy had been officially delinquent he might conclude that his chances for doing well in school were impaired.

3. There was a high relationship between self-reported behavior and reported behavior of friends, but not between such behavior and number of friends one knew who had been in trouble.

4. The measurement for occupational goals was not valid or seventh graders were too young to have developed meaningful goals.

5. The boys' self-reported anticipated behavior was related to his self-reported behaviors but not to officially recorded behavior. The inference was that punishment, which usually followed officially recorded behavior, was not a deter rent.

6. The boys who ran around with friends in their own neighborhood were the ones most likely to get into official trouble. Since one's friendship ties were not related to self-reported bad behavior, the inference 
arose that this variable affected the police and school officials' response.

7. Having one's father as a companion correlated negatively with officially reported delinquent behavior but not with self-reported behavior which might indicate this variable affected the delinquency control agencies. ${ }^{1}$

The staff of the Center felt that any conclusions from the Student Opinion Survey were tentative, but that the findings seemed to challenge some of the commonly held notions about the nature of deviation and social control. One of these suppositions to be challenged was that deviate behavior can be either adequately described or explained by the characteristics of the person himself. A description of the characteristics of the person alone was inadequate in accounting for officially reported deviate behavior. In order to explain this behavior one would have to know something about the characteristics of the society that responds to the behavior. One would also wonder what impact it has on individuals to have been labelled as troublemakers. 2

\section{CONCLUSIONS}

The research reviewed above re-enforced my feeling that exploratory studies were pertinent in the field of juvenile delinquency

${ }^{1}$ Seattle Atlantic Street Center, Fourth Year Progress Report, Gould, op. cit., pp. 1-58.

2 Ibid., pp. 62-64. 
and was used in developing the method of this particular research project, discussed in Chapter IV. 


\section{CHAPTER IV}

\section{THE RESEARCH PROCESS}

In the spring quarter of the academic year of 1967 , a group 1 of which I was a member reviewed the literature and discussed ways of doing research about institutionalized juvenile delinquents returned to their communities. As I was particularly interested in what was happening in Alaska, ${ }^{2}$ I inquired of the Alaska State Youth and Adult Authority about permission to interview their releasees and was assured of the Division's interest and help. ${ }^{3}$ Since it was probable a sample of 20 would be available and other sources of information were also accessible, the summer months of 1967 seemed an appropriate time for collecting data in Ketchikan. There was available an instrument that was suitable for the kind of exploratory study I wanted to do, the Student Opinion Survey of the Seattle

${ }^{1}$ See Chapter I, p. 1.

2 The author and her husband were employed as the first houseparents of the Ketchikan Children's Home, February, 1955, prior to the author's employment as child welfare worker for the Division of Public Welfare. See Chapter I, p. 1.

${ }^{3}$ Letter from Richard B. Lauber, who was then Director, Division of Youth and Adult Authority, Juneau, Alaska, March 23, 1967. He assigned Keith Anderson, Project Director, Youth and Adult Authority, as liaison. 
Atlantic Street Center Study. ${ }^{1}$ It had already been tested.

\section{RESEARCH DESIGN}

From then I planned and carried out the project according to the following schedule. In the early days of the summer of 1967 , the Student Opinion Survey was adapted for use by selecting those items that had yielded statistically significant data. Three additional questions about employment which were included might have been significant had the Center's sample contained more adolescents. I then formulated a series of tentative null hypotheses using the variables those items measured.

In mid-July, the Ketchikan Office of Youth and Adult Authority ${ }^{2}$ furnished the list of releasees from which the study group was found. Simultaneously the pretest was done, and the questionnaire completed. Next the final form of the questionnaire and the method of the interview and recording were decided upon. The study group and the control group were established. Between the dates of July 16, 1967, to September 13, 1967, I interviewed and administered the questionnaire in person to each available respondent in both groups. I recorded the interviews and material from

${ }^{1}$ Gould, Fourth Year Progress Report, op. cit.

2 Interview with Curtis McDaniels, Probation Officer, Ketchikan Youth and Adult Authority Office, July 13, 1967. 
official records. In the academic year 1967-68, I organized the data so they could be better managed and analyzed them statistically.

\section{PRETEST}

The two pretests were conducted individually with a 19-yearold half-Tlingit youth who was a releasee from a correctional institution and a 15-year-old Caucasian boy who had no delinquency record. Only two youths took part in the pretest because more would have impinged on the small number comprising the sample. There would have been danger of contamination among the total research group from communication with the respondents to a formal pretest. With a questionnaire that had been tested in use the two were deemed adequate to test feasibility.

I talked with each boy: alone about the research project and explained that his participation would help evaluate the method planned for use. I administered the questionnaire individually. The boys gave their opinions about the content and form of each item in relation to its applicability for young people of Ketchikan. How their recommendations were used is described under the final formulation of the questionnaire.

The responses to the two pretests show a picture of the interview and the interrelatedness of the interview, the questionnaire and the information from official records. 
The 19-year-old's answers for the most part correlated with his records. He checked seven of the nine self-report items detailed in Table $I$ in the affirmative. His report of friends' behavior indicated that his friends had committed all the acts on the nine-item scale--five of the acts over nine times. About anticipated future behavior, he answered each time "no," which did not correlate with his record the rest of the summer.

TABLE I

QUESTIONNAIRE: SELF-REPORT OF DELINQUENT BEHAVIOR

\section{A. Own Behavior}

Question 1. Have you ever done any of these things? Circle answer yes or no. If your answer is yes, circle answer how often.

a. Driven a motorcycle without Yes No a driver's license? If so, 0 1-2 3-9-More than 9 how often?

b. Driven a car without a Yes No driver's license? 0 1-2.3-9 More than 9 If so, how often?

c. Disobeyed your parents' Yes No authority to their face. If so, how often?

0. 1-2 3-9 More than 9

d. Taken little things that Yes No did not belong to you? If so, how often? 
e. Bought or drunk beer, wine. Yes No or liquor (including drinking at home)? If so, how often? 0 1-2 3-9 More than 9

f. Run away from home? If so, how often?

Yes No

0 1-2 3-9 More than 9

g. On purpose, damaged, or Yes No destroyed things that did not belong to you? If so, how 0 1-2 3-9. More than 9 often?

h. Threatened another kid Yes No for money? If so, how often?

0 1-2 3-9 More than 9

i. Beat up kids or adults who Yes No haven't done anything to you? If so, how often?

$\begin{array}{lllll}0 & 1 & -2 & 3 & -9\end{array}$ More than 9

\section{B. Friend's Behavior}

Question 8. Have any of your close friends ever done any of these things? Circle answer yes or no. If yes, circle answer how often. Items (a) through (i) same as in Question 1 .

\section{Anticipated Behavior}

Question 11. Do you think you might do any of these things in the future? If so, how often? Circle answer yes or no. If answer yes, circle how often. Items (a) through (i) same as in Question 1.

In answer to the questions about community norms listed in

Table II, he replied that most people would say a person should finish high school; he wanted to finish high school, but he thought he would 
get no further than ninth to eleventh grade. He had re-entered high school after his release into the community. He had been absent from school three times due to getting drunk and consequently being held in the Ketchikan Jail. He had dropped out of school. His inference was that his expectations had been lowered by his official trouble. After I studied his official records, my conclusions were that, prior to his experience in the correctional school, he had expected to finish high school.

This young man thought the occupation of physician led to the greatest success, and he thought that this was the one profession he would have the least chance of attaining.

TABLE II

QUESTIONNAIRE: ATTITUDE TOWARD COMMUNITY NORMS

A. Education

2. How far do you think most people would say: a person should go in school

a. 8th grade before he quits and begins working?

b. 9-11th grade

c. senior high school

d. community college

e. a year or two of college

f. vocational school

g. college (4 years or more)

3. How far do you yourself want to go in school? Items (a) through (g) same as in 2 .

4. How far do you think you will actually get before you quit school? Items (a) through (g) same as in 2 . 


\section{B. Occupation}

5. Write the jobs on the rungs of the ladder, placing at the top the job that you think would lead to the most success, and at the bottom the job that you think would be least successful.

The jobs are:

a. Owner of a lunch stand

b. Manager of a grocery store

c. Accountant-bookkeeper

d. Owner of a manufacturing company

e. Electrician

f. Janitor

g. Physician (doctor)

h. (Pulp Mill) engineer

i. Truck driver

6. Now place those jobs on this ladder, placing the job you would like best to have at the top, and the one that you would like least to have at the bottom.

Items (a) through (i) same as in 5.

7. Place the jobs on this ladder, placing the job you think you have the best chance of having at the top, and the one that you think you have the least chance of having at the bottom. (This means your best chance of having it in a few years - not now.)

Items (a) through (i) same as in 5.

The questions about friends included in Table III elicited replies that the respondent knew more than ten young people who had been in trouble and in court. 
TABLE III

QUESTIONNAIRE: DELINQUENT FRIENDS

9. How many young people (under 21) do you know who have ever been in trouble with the police for other than a traffic violation: Circle answer.

None one or two three-five six-ten More than ten

10. How many young people do you know (under 21) who have been taken to District or Juvenile Court? Circle answer.

None one or two three-five six-ten More than ten

His responses to the questions of Table IV indicated that if he committed any of the acts on the self-report scale of Table I, he thought his parents, the police, the neighbors and his friends would likely know. He responded it was unlikely that anyone would do anything about his behavior except the police. It was very likely the police would do something about his behavior. 
TABLE IV

\section{QUESTIONNAIRE: PERCEPTION OF COMMUNITY}

REACTION TO DEVIANCE

\section{A. Likelihood of Discovery}

12. Let's imagine for a moment that you had done each of the se things, listed in question 1 . How likely do you think it would be that your parents would find out about it? Circle answer.

Very likely Likely Unlikely Very unlikely

13. If you were to do these things, how likely do you think it would be that your neighbors would find out about it?

Very likely Likely Unlikely Very unlikely

14. If you were to do these things, how likely do you think it would be that your friends would find out about it?

Very likely Likely Unlikely Very unlikely

15. If you were to do these things, how likely do you think it would be that the police would catch you?

Very likely Likely Unlikely Very unlikely

B. Likelihood of Punishment

16. If your parents found out that you had done these things, how likely do you think it would be that they would punish you?

Very.likely Likely Unlikely Very unlikely

17. If the police caught you doing these things, how likely do you think it is that they would do anything about it?

Very likely Likely Unlikely Very unlikely

18. If your neighbors found out that you had done these things, how likely do you think it is that they would do anything about it?

Very likely Likely Unlikely Very unlikely 
19. If your friends found out that you had done these things, how likely do you think it is that they would do anything about it?

Very likely Likely Unlikely . Very unlikely

His answers to the items of Table $\mathrm{V}$ indicated he had liked his neighborhood and that he had close friends going to his school, running a round in a group and living in his neighborhood.

TABLE V

QUESTIONNAIRE: INTEGRATION IN NEIGHBORHOOD

20. Do you like the neighborhood you live in?

Very much Somewhat Not very much Not at all

21. How many of your close friends live in your neighborhood?

$$
0-3 \quad 4-7 \quad 8 \text { or more }
$$

22. How many of your close friends went to your school?

$$
0-3 \quad 4-7 \quad 8 \text { or more }
$$

23. How many of your close friends ran around together in a group?
$0-3$
$4-7$
8 or more

His replies to questions about activities in Table VI correlated with official information about his family and friends.

In the second pretest the 15-year-old with no delinquency 
record gave responses inversely related to those of the first respondent. He reported no delinquent acts for himself. He reported minimal delinquent acts for friends. He thought most people would say a person should finish high school. He himself wanted to finish college. He consider the owner of a manufacturing company the most successful. He expected to own a store. He knew a few people who had been in trouble. He thought his parents would do something about any trouble he was in, but the police would not. He liked his neighborhood; he had close friends living in his neighborhood, running around in a group, and going to his school. His replies to questions about activities correlated with information about him.

TABLE VI

QUESTIONNAIRE: ACTIVITIES

\section{A. Which Activities}

24. What kinds of activities did you usually participate in? Club meetings or club activities

Very frequently Quite often Sometimes Seldom Never

Dances or parties*

Ba seball

Church activities

Ba sketball

Movies

Honda riding

Fishing or hunting

Boating

Picnics

Loafing

*The categories were the same after each activity as itemized after club meetings. 
B. Companions in Activities

25. Who usually accompanied you to these activities? Put a check after the person who did any of these things with you.

Father

Mother

Brother

Sister

Other relatives
Friends

Gal or Guy

Gang

No one

26. If you checked that you participated in the activity in question 24 at all, write in the space after these questions one of the above persons or no one.

Who usually accompanied you to dances or parties? Who usually accompanied you to church activities? Who usually went with you to the movies? Who usually went with you fishing or hunting? Who usually went with you on picnics? Who usually went with you to baseball? Who usually went with you to basketball? Who usually went Honda riding with you? Who usually went boating with you ? Who usually loafed with you?

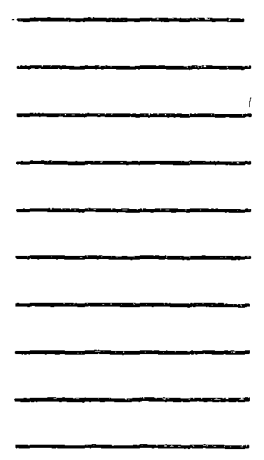

Both of the boys agreed that the items in the questionnaire were of concern to young people, and they felt youth in this area would be willing to participate. Since the pretest number was small, I took opportunities throughout the summer to give the questionnaire to and discuss it with other young people who were not in the sample or control group. 


\section{FINAL FORMULATION OF THE QUESTIONNAIRE}

The final form of the questionnaire ${ }^{l}$ resulted from my choice of items from the Student Opinion Survey ${ }^{2}$ and my discussion of these items with the two pretested boys.

Question 1 of the questionnaire in Table I, Items (b) through (i), came directly from the Student Opinion Survey. ${ }^{3}$ The younger boy, in the pretest, suggested Item (a). The older youth recommended adding the "or adults" in Item (i). This young man knew that many of the respondents would be older adolescents or young adults. The record showed that he had beaten an older cab driver. I chose Question 1 as an index of the actual incidence of behavior of both groups. The self-report index would also indicate how the young persons felt about themselves. Using the index for the report of friends' behavior in Question 8 and about future behavior in Question 11 would obtain the group members' self-image. How the members saw their friends' behavior and how the members thought of their future behavior might prove to be indicative of their self-concept. The responses to the question about friends' behavior also might indicate whether the respondents' behavior was a group phenomenon and had group sanction or whether the behavior was lone behavior.

${ }^{1}$ See Appendix, p. 117-26: ${ }^{2}$ Gould, op cit. ${ }^{3}$ Ibid., p. 5. 
To throw more light on the relationship of officially reported delinquent behavior, perception of the community norms and anticipated and aspired-to educational and occupational goals, Questions 2 through 7 in Table II were chosen. The educational goals were similar to those of the Student Opinion Survey ${ }^{1}$ except for the category: "9th to 11 th grade" advised by the older pretested youth. The list of occupations in the Student Opinion Survey ${ }^{2}$ for Questions 5, 6 and 7 , were modified silightly.

Staff of the Seattle Atlantic Street Center had designed Questions 8 , 9, and 10, in Table III to test the hypothesis: "The more contact of certain kinds one has with others who exhibit delinquent behavior, the greater are the chances one will engage in delinquent behavior oneself. " ${ }^{3}$ I chose Questions 9 and 10 primarily to relate

${ }^{1}$ Gould, op. cit. , p. 19.

2 Ibid., p. 25, citing C. C. North and Paul K. Hatt, "Occupational Status and Prestige," Robert O'Brien, et al., Readings in General Sociology (Boston: Houghton, Mifflin, $\overline{1} \overline{957}$ ), pp. 352-358. The nine occupations drawn from the North-Hall scale of occupational prestige included: owner of a lunch stand, manager of a grocery store, accountant, owner of a manufacturing company, electrician, janitor, physician (doctor), (Boeing) engineer and truck driver.

3 Ibid, p. 30, citing Edwin H. Sutherland, Principles of Criminology (Philadelphia: Lippincott, 1947), "but it has also been stated" by Clifford Shaw and Henry D. McKay, Juvenile Delinquency and Urban Areas (Chicago: University of Chicago Press, 1942) and Richard Cloward and Lloyd Ohlin, Delinquency and Opportunity: A Theory of Delinquent Gangs (Glencoe: The Free Press, 1960). 
the results to self-concept.

The 19-year-old suggested that District Court be added to Juvenile Court in Question 10. He pointed out that although the Juvenile Court has the power to commit a young person until age 21 to the Department of Health and Welfare, any new charges against a person after age 18 are heard in the District Court. ${ }^{1}$ He added that some of the sample group would be over 18 .

Questions 12 through 19 in Table IV were chosen to ask the respondents' perception of likelihood of punishment. Questions 20 through 23 in Table $\mathrm{V}$ might indicate the degree to which the respondents were integrated into their neighborhood. ${ }^{2}$ The possibility that the questions might accomplish these two points was in accord with Clifford Shaw's and Henry McKay's argument that well-integrated communities were better able to control deviant behavior than poorly organized communities. ${ }^{3}$

The activities in Question 24 in Table VI came directly from the Student Opinion Survey ${ }^{4}$ with the following exceptions. I divided

1 The same Judge served both courts.

2 Ibid, , p. 30 , citing Edwin H. Sutherland, Principles of Criminology (Philadelphia: Lippincott, 1947), "but it has also been stated" by Clifford Shaw and Henry D. McKay, Juvenile Delinquency and Urban Areas (Chicago: University of Chicago Press, 1942) and Richard Cloward and Lloyd Ohlin, Delinquency and Opportunity: A Theory of Delinquent Gangs (Glencoe: The Free Press, 1960).

3 Ibid.
4 Ibid., pp. 53-58. 
sports into categories, baseball and basketball, the two main organized sports of Ketchikan. The 15-year-old boy suggested the categories Honda riding, boating and loafing. Boating was a logical sport to add for Ketchikan where life is oriented to water. The boy who suggested loafing conceived loafing as an active period of relaxation while marshalling one's forces for the next, more outgoing activity.

The Student Opinion Survey ${ }^{1}$ had designed Questions 25 and 26 in Table VI for boys only; therefore "gal" meant the friend of the opposite sex; so I changed "gal" to "guy" for the girls of my two groups.

Concurrently with completing the formulation of the questionnaire the guide lines for the interview took shape. They were subsequently followed, with the exception that I asked more about the respondents' knowledge of their family history than I had planned in the guide lines. Some examples are in the section. "Integration in the Neighborhood", page 70.

I kept information in duplicate. A copy of the format is in the appendix. $^{2}$. While the research process was going on, I identified my records by a number assigned to the respondent rather than by name.

$1_{\text {Ibid. }}$

${ }^{2}$ Appendix, p. 116 
IV. THE YOUNG PEOPLE OF THE STUDY GROUP AND CONTROL GROUP

The Chief Probation Officer ${ }^{1}$ of the Ketchikan District Office of the Youth and Adult Authority prepared a list of the most recent 19 releasees from correctional institutions into the community of Ketchikan. Of the 19, I found 15, 3 girls and 12 boys. All of the 15 agreed to participate and comprised the study group. I thought the re would be more. I asked for a list that would include the last 20 releasees in the past year or two. He gave me a list that went back two years. I decided it would be better to have a smaller sample than to try to include members who had been released longer ago than that, because of age, recall and locating difficulties.

The control group was from a list of 22 students. The viceprincipal ${ }^{l}$ of Ketchikan High School looked over the high school rolls for the past four years, matching as to sex, race and age the 19 of the preliminary study group. Of 22 pos sible controls, 20 were found: 6 girls and 14 boys. Two Haida of the 20 did not wish to participate. The mother of one gave as an excuse the boy's embarrassment about his own delinquency. The other Haida did not keep appointments she made with me. The other 18 agreed to participate.

\footnotetext{
${ }^{1}$ Interview with Curtis McDaniel, July 13, 1967.

Interview with Richard D. Hansen, August 21, 1967.
} 
The nineteenth name in the final control group, and the fourteenth boy, was a boy in Klawock I selected additionally to match a Klawock boy in the study group.

\section{OFFICIAL RECORDS}

Some of the information obtained from the official records of Youth and Adult Authority, Ketchikan Police Department and the Division of Public Welfare is discussed here. Although I did not ask the respondents this kind of information and did not have the official record at the time of the interview, the observations from those records about the following variables give more meaning to the succeeding subdivision, "Interviews" and Chapters V and VI.

\section{Observations about Institutional Placement}

The members of the study group had been moved from home to an institution or from one institution to another a minimum average of 4.87 times. They had been away from home an average of 1. 6 years, a range of time from nine months to three years.

Four of the 12 boys had gone only to the correctional institution, the Alcantra Youth Camp. Those four had been in a minimum of three institutions each: the Ketchikan Alaska State Detention Home, the Anchorage State Jail enroute to the Youth Camp and the Youth Camp. 
Six of the seven boys placed at the Federal Correctional Insti tution at Englewood, Colorado, or by California Youth Authority had been at Alcantra Youth Camp, first. The twelfth boy had been at the MacLaren School for Boys in Oregon and was supervised in Ketchikan under the Uniform Reciprocal Agreement. ${ }^{1}$

The three girls had varied experiences. One came from Fort Worden Treatment Center in Washington and was supervised here under the Uniform Reciprocal Agreement. The two local girls had been detained in the Detention Home and placed with California Youth Authority; one of them had also been in a Home of the Good Shepherd in Montana and in the Billings' Jail after a runaway from that home.

Six of the 19 members of the control group had been in the Detention Home once for a day or two and none had been in a correctional school. The records showed innumerable runaways from the Detention Home and Alcantra Youth Camp for the study group but no management problems for the control group during the short periods of time its members had been detained.

As of July 13, 1967, the young people of the study group had been home in the community from the last correctional school commitment an average of 9.21 months; the time ranged from two years one month, to one month.

${ }^{1}$ See Chapter I, p. 7. 
Institutional Placements Since Release from Correctional School

Since the respondents' return to the community, ten of them had been in jail because of violations relating directly or indirectly to alcohol. Only one of the 15 had been incarcerated since his return to the community, for a felony.

\section{Offense Record}

The Ketchikan Police Department had known the members of the study and control groups as juveniles under 18 for the violations as shown in Table VII. The table shows that the number of official offenses of the study group, 82, compared with 14 offenses of the control group.

\section{Population Characteristics}

The girls of the study group averaged one year three months younger than the girls of the control group as is shown in Table VIII. The boys' age in each group averaged about the same, although the age range was less in the study group of boys. The study group as a whole averaged nine months younger than the control group, as a result of inexact matching. 
TABLE VII

OFFENSE RECORD OF THE MEMBERS OF THE STUDY AND

CONTROL GROUPS, FROM CONTACT SLIPS OF THE

KETCHIKAN CITY POLICE DEPARTMENT ON

FILE IN THE YOUTH AND ADULT

AUTHORITY OFFICE

\begin{tabular}{lcc}
\hline \multicolumn{1}{c}{ Offenses } & Study Group & Control Group \\
\hline & 20 & 2 \\
Liquor violations & 10 & 3 \\
Petty larceny & 10 & 1 \\
Curfew violations & 8 & \\
Burglary & & \\
Referred to YAA - no & 7 & \\
offense checked & 6 & \\
Larceny & 5 & \\
Shoplifting & 1 & \\
No driver's license & 1 & \\
Disturbance & 1 & \\
Breaking and entering & 1 & \\
Resisting arrest & 1 & \\
Investigation & 1 & \\
Questioning & 1 & \\
Forgery & 1 & \\
Runaway & 1 & \\
Accident & 1 & \\
Molesting auto & 1 & \\
Other & 1 & \\
Vandalism & 1 & \\
Injured person & 1 & \\
No offense checked & 1 & \\
Trespassing & & \\
Malicious destruction & & \\
of property & & \\
Traffic citations & & \\
& & \\
\hline \hline
\end{tabular}


TABLE VIII

AGE OF RESPONDENTS OF STUDY AND CONTROL GROUPS, JULY 13, 1967

\begin{tabular}{|c|c|c|c|c|}
\hline Sex & $\begin{array}{l}\text { Age Range of } \\
\text { Study Group }\end{array}$ & $\begin{array}{c}\text { Mean } \\
(\text { Years) }\end{array}$ & $\begin{array}{l}\text { Age Range of } \\
\text { Control Group }\end{array}$ & $\begin{array}{c}\text { Mean } \\
\text { (Years) }\end{array}$ \\
\hline \multirow[t]{2}{*}{ Girls } & $\begin{array}{c}14 \text { years } 5 \text { months } \\
\text { to }\end{array}$ & & $\begin{array}{c}15 \text { years } 2 \text { months } \\
\text { to }\end{array}$ & \\
\hline & 17 years 3 months & 15.97 & 18 years 7 months & 17.2 \\
\hline \multirow[t]{2}{*}{ Boys } & $\begin{array}{c}15 \text { years } 9 \text { months } \\
\text { to }\end{array}$ & & $\begin{array}{c}14 \text { years } 9 \text { months } \\
\text { to }\end{array}$ & \\
\hline & 20 years & 17.87 & 20 years 5 months & 17.94 \\
\hline
\end{tabular}

The closeness of the matching of sex is shown in Table IX. Percentages where shown, throughout the thesis, are for ease of comparison, regardless of the significance of differences.

TABLE IX

SEX OF RESPONDENTS OF STUDY AND CONTROL GROUPS

\begin{tabular}{lcccc}
\hline \multicolumn{2}{c}{ Sex } & \multicolumn{2}{c}{ Study Group } & \multicolumn{2}{c}{ Control Group } \\
Girls & $\mathrm{N}$ & 25 & $\mathrm{~N}$ & $\%$ \\
\multirow{2}{*}{ Boys } & 3 & $\frac{75}{100}$ & $\frac{14}{19}$ & $\frac{73.7}{100}$ \\
& $\frac{12}{15}$ & & & 26.3 \\
\hline
\end{tabular}


The proportions of identifiable racial or linguisitic groups represented are shown in Table X. Eleven of the study groups were indigenous to Alaska. The one Norwegian was the grandson of an Alaska pioneer; the Japanese was the son of a recent post-war immigrant to Alaska. The mixed Caucasians had been released into Alaska from other states. The disproportionate number of indigenous Alaskans on the list made it obvious that race was a significant factor in delinquency in this area in some form or another.

TABLE X

PROPORTIONS OF IDENTIFIABLE RACIAL OR LINGUISTIC GROUPS REPRESENTED BY RESPONDENTS

\begin{tabular}{|c|c|c|c|c|}
\hline \multirow{2}{*}{$\begin{array}{c}\text { Racial or } \\
\text { Linguistic } \\
\text { Group }\end{array}$} & \multicolumn{2}{|c|}{ Study Group } & \multicolumn{2}{|c|}{ Control Group } \\
\hline & $\mathrm{N}$ & $\%$ & $\mathrm{~N}$ & $\%$ \\
\hline Haida & 6 & 40 & 2 & 10.53 \\
\hline Tlingit & 4 & 26.67 & 6 & 31.63 \\
\hline Mixed Caucasian & 2 & 12.34 & 4 & 21.05 \\
\hline Norwegian & 1 & 6.67 & 1 & 5.26 \\
\hline Tsimpshian & 1 & 6.67 & 4 & 21.05 \\
\hline Japanese & 1 & 6.67 & 1 & 5.26 \\
\hline Eyak & & & 1 & 5.26 \\
\hline Total & $\overline{15}$ & $\overline{100.01} *$ & $\overline{19}$ & $\overline{99.04} *$ \\
\hline
\end{tabular}

*Per cent not even because of rounding off errors.

The fact, too, that the matching process resulted in a study group of 40 per cent Haida and a control group of 10.53 per cent Haida, as well as inexact matching of Tlingit and Tsimpshian raised 
the question as to whether or not any future study of this kind should not match the linguistic groups; or nations rather than race.

Records of intelligence and achievement were not complete.

High school records showed that 36.84 per cent of the control group were considered to be below average in achievement or intelligence. The records of the probation office showed that 53.33 per cent of the study group seemed to be below average in achievement or intelligence. This information came from different sources and was not strictly comparable.

\section{INTER VIEWS}

First, I telephoned the respondent, if his family had a telephone. I talked to his family or himself, whoever was available. If the family had no telephone or was away, from Ketchikan, I wrote a letter asking him to write me or call me collect. If he didn't respond, I went to him. Each person and his family, in both groups, agreed to the interview, except for the two of the control group already discussed. ${ }^{1}$

Conditions of the interviews were varied. The approach was consistent. I introduced myself and explained who had referred the respondent, He was told the project had to do with research that

${ }^{1}$ Page 52. 
was being done in Portland and with my going to school and that his help was needed. With the study group, I emphasized that I was not there to help or to check up on the respondent nor to require his help. This was his opportunity to help other boys and girls and to say what he wanted to say about having been in trouble. ${ }^{1}$

I explained that all information would be used for this research only without identifying names. It meant an hour of his time, spent in discussion and in filling out the questionnaire.

I gathered information in the interview to test the validity or truth of the responses of the questionnaire. Sometimes the respondent began talking in response to the general introduction. I had in mind a list of questions to ask and significant people ${ }^{2}$ to inquire about. The plan for the interview was followed with one exception. 3 The first question was about how it had been or how it had felt in correctional school. Some of the respondents knew me and knew that I had not wanted them to have to go. I asked them in addition how they had gotten along since they came home, what gathering places theyvisited, whether they had work and how school had gone. The questionnaire began with a question about own behavior that

${ }^{1}$ Gisela Konopka, The Adolescent Girl in Conflict (Englewood Cliffs, New Jersey: Prentice-Hall, Inc., 1966), p. 12 .

$$
{ }^{2} \text { Appendix, p. } 126 \quad{ }^{3} \text { See p. 51, } 70 .
$$


might have been threatening had there not been the preparation of the interview.

Interviews took place from July 16, 1967, to September 13, 1967, in the welfare office, the person's home or foster home, the jail, other institutions and elsewhere. The welfare office facilities were good for private interviewing, and convenient for me, so respondents who were able and willing, came there.

At the same time; I was willing to go anywhere else. For example, I left Ketchikan August 30, 1967, for a day's trip to Klawock and return via Grumman Goose. The respondent, who knew of my coming, was waiting at the dock for the amphibious plane, in the pouring rain. I told him that I had never seen Klawock and wanted to. We walked up the main street, by the modern elementary school to the totem park. He shyly acknowledged one Raven pole as his family's, in answer to my query. We visited his house so that I could greet all his family. There was no privacy for the interview there. The Alaska Native Brotherhood Hall, the Pentecostal Church and the Salvation Army Hall, the only public buildings other than the school, were closed, as was the school. The one grocery store was open part of the day. We stood under the porch roof of the Alaska Native Brotherhood Hall while the respondent filled out the questionnaire. That day, Klawock, in the drenching rain, had a quietness that was broken only by the "kla wock" of the ravens on the beach. 
I was weather-bound for three days and stayed in a noisy inn above a bar on a beach in Craig, road-connected to Klawock. This illustrates how I saw some of the respondents on their own terms and what kind of experiences brought home the respondents' and my closeness to the geography, the weather and wilderness, of this land of contrasts.

All of the respondents but one gave responses that seemed normal. The responses of the Norwegian of the study group, the only local Caucasian of this group, were bizarre confabulations. He was interviewed in the Juneau State Jail. He was the only one of the study group convicted of a felony since release from correctional school. He smoked constantly, and his fingernails were bitten to the quick.

One of the boys who didn't know me told me that he "goofed around" with his questionnaire--and he kept the interview brief and superficial.

One of the first things I asked in the interview was how it had been in the correctional school. One girl explained, "I suppose it helped because I felt so horrible there. "

One boy thought:

It all depended on the person. I myself went to Youth Camp and came back a man. . . . The counselors were helpful at camp. I was the most trusted boy. At Christmas for example, of all the boys I was the one who was permitted to go out alone for hours to find the right Christmas tree for 
the camp. A month after I was there I became a trustee which meant that I was a trusted boy; then I had another appointment and the third appointment which meant I was a most trusted boy. I liked it at camp.

These have been examples of the varied ways respondents described their time in the correctional schools.

Some of the responses about how they felt about the experience after they were home, and how they reflected others' feelings about it are as follows. The boy quoted above said, "I get hurt by my sisters and brothers who say to me, 'At least I've never been in prison. ' I wanted to come home but now I wonder why. "

Another boy explained, "After I was in Detention overnight, the kids teased me saying, 'What kind of bird doesn't fly? A jail bird. "'

Alcantra Youth Camp was called "Little Alcatraz" by the boys. One boy threw more light on the youths' feelings. "Even the 'Ingroup' who thought it was the thing to do to be snotty with police and be placed in Detention were down on the ones that went to Youth Camp and other places."

Some of the other respondents said that it made no difference to their families or friends that they had been away, and that everything felt the same to them.

The remaining discussion about the kind of information obtained in the interviews is divided into the subheadings of the six topics of 
the questionnaire as shown in Tables I through VI.

\section{Self-Reported Behavior}

Some of the kinds of things the respondents said thatilluminated. items listed in Table I are quoted here. There were no comments pertaining to Items (a), (b) or (i). The examples of own behavior often included examples of friends' behavior.

Item c. One of the local girls said, "I acted hateful to my Mom and Dad, cussed and all when I got out of reform school. I felt hateful."

Another young lady said:

When I first got home I got along all right with my mother. Then I started staying out late and my mother called me all kinds of nasty names like tramp--and things just got worse at home. I just didn't try to stay with my mother anymore.

Some of the control group did not mention their parents and none of them mentioned them with derogation. One boy said that he would not want to hurt his parents. Another one said that his father would do anything for him. The Japanese boy said that he was being raised like an American and not in Japanese tradition because his mother, not he as eldest son, came first in his family.

Item d. The only detailed accounts of stealing were by the young adult who was in the Juneau Jail on the felony charge, who recited his offenses glibly. Another comment was by a member of the control group who said that stealing really wasn't considered bad 
by a great number of his peer group.

Item e. One respondent of the control group commented, "There is lots of drinking. The girls I know begin at 13. All the kids I know drink. "

Another self-report from a respondent of the study group was: "Here with my old friends I do more drinking. Here I walk around and walk around and go to the Northland until someone comes up and asks me if I want to get drunk."

Consistently the respondents had comments about the drinking, indicating that all had given this activity a lot of thought.

Item f. See Item c.

Item g. One study group member commented: "I remember destroying things that weren't mine--in detention. There was not enough air and not enough light; some of the windows were boarded up--so I and my buddy hit out the windows."

Item $h$. One respondent said that:

Kids up here don't fight with razors or knives. Fists are used and seldom feet. I would fight anyone who ran down my family, made fun of my family or put me down. One boy who was made fun of because he looked more white than Indian fought four or five people with no help.

Another young man said:

Two or three years ago if the young Coast Guard men or any of the other young fellows from Puget Sound who came up here tried to take the women--right then and there, there was a rumble among the teenagers. The teenagers here are big and used to work and they are something to 
deal with. I remember one time two or three years ago when two of the policemen went in to stop a rumble and came out on their hands and knees. Ketchikan has quieted down quite a bit--maybe the word has gotten out to the Coast Guard men to leave the women alone here.

Most of the respondents anticipated drinking in the future; for members of the study group this seemed to be with a feeling of selfworthlessness and hopelessness.

\section{$\underline{\text { Attitude Toward Community Norms }}$}

The control group had plans for school in the fall, except for two members who were this year's high school graduates. Table XI shows the frequency distribution of the school grade completed by the respondents. This information came from the interviews and from Ketchikan High School records. The mean of grades of school completed for the study group was 7.92 and for the control group 11 plus.

The study group had comments to make about school like this: "When I came home from the correctional school I thought I'd reenter school, and then I remembered how it was. I didn't go back."

Other young men implied that the problems in attending a school now were because of their age and their relationship with peers. They said that they had received considerable encouragement from teachers, but they just couldn't stay in school.

Of the study group 53.33 per cent did not re-enter school. 
TABLE XI

FREQUENCY DISTRIBUTION OF SCHOOL GRADES COMPLETED

BY MEMBERS OF STUDY AND CONTROL GROUPS

JULY 13, $1967^{1}$

A. Three Girls of Study Group

School Grade Completed

7 th

8 th

9 th

Number

1

1

$\frac{1}{3}$

B. Five Girls of Control Group

9 th

10 th

11 th

12 th

6 th

7 th

8 th

9th

9 th

10 th

11 th

12 th

13 th

14.th
1

1

1

$\frac{2}{5}$

C. Twelve Boys of Study Group

1

3

5

$\frac{3}{12}$

D. Fourteen Boys of Control Group

1
3
5
$\frac{3}{2}$
s of Control Group

8. 32

25. 00

41.67

25. 00

99.99

14. 29

0

14. 29

28. 57

28. 57

0

$\frac{14.29}{100.01}$

I Information from Ketchikan High School records and from interviews. 
Forty-six per cent returned to school. Of the 46 per cent only 2 , or 13. 13 per cent of the study group remained in school. One was a girl from Washington now living in Ketchikan; and the other a girl from Ketchikan who now lived in California. In other words, none of the youngsters was in school in his own community. Prior to the young people's leaving the community for correctional schools, only one had experienced school management as his main problem.

For four, school had been no problem at all; for six, school management had been a secondary problem; for four, the official records and the interviews were not clear.

Not one of the young people advanced academically while he was in correctional school. Being placed seemed to have been synonymous with the ending of the young person's academic education.

All of the control group reported employment, while only 25 per cent of the study group had employment.

$\underline{\text { Delinquent Friends }}$

Some of the members of the control group mentioned delinquent friends. The study group evidenced knowledge of and as sociation with one another.

It was not until the winter of 1967 when I was evaluating the information from the welfare office records from a geneological 
standpoint that I realized that of the six Haida of the study group, three had the same great grandmother. Two others of the six were relatives of those three. The one who was referred for the control group who refused to participate because of his own delinquency record was a relative of these five Haida. This raises the question of the significance of their relationship. Was it significant or can a relationship be found for almost all Haida of this generation?

This great grandmother was from Victoria, British Columbia. If a women were here in Kaigani Pass from Victoria, British Columbia, was she not a slave? If this were so did the respondents' descent from a slave affect their peer reiationships now in the community of Ketchikan? Whether or not the aboriginal status affects present social adjustment is a question worthy of further pursuit.

\section{Perception of Community Reaction to Deviance}

A young man of the study group told me:

I knew when I went up the mountain drinking that day that I was running a risk. I hadn't been drinking at all for five months but I'd broken with my girl friend that weekend and so that's what happened. I'd run a risk and lost. . . . We always know when we drink that we are running the risk of getting caught, but we do it anyway.

One respondent of the control group said, "The kids who get caught are the ones who have to go downtown to show off that they've been drinking."

One of the girls said, "The 'in-group' are as wild as the others, 
but the 'in-group' has parents who get them out of trouble if they are caught. The others get caught and no one gets them out."

The respondents were consistent that race didn't enter into this. The problem was where you drank, whether you were caught and how you behaved when you were caught.

Integration in Neighborhood

In the interviews no obviously universal attitudes appeared. There were occasional comments by the study group members about doing better down south in neighborhoods where they weren't known.

Here I will discuss the one exception I mentioned ${ }^{l}$ that was included in the interviews. The respondents reminisced more freely than I had anticipated about their cultural history. It seemed that in a setting such as this research project, with more time, and with less stress than in interviews centered around a crisis to solve, more knowledge of their former culture was discussed. Their closeness to this former culture would be a factor in their integration in Ketchikan today. Respondents who were indigenous Alaskans knew to which matrilineal clan they belonged. All of them who were asked had an Indian name. There were indications that the names given were names of ancestors and that some belief in reincarnation of the spirit of the ancestor was held by the family who gave the

${ }^{1}$ See p. 60. 
name, if not by the youth of today who had the name.

Chief Skowl, a great Haida Chief, ${ }^{1}$ was the "great grandfather of one of the respondent's uncles, "according to the respondent.

One of the boys of the study group who lives in Ketchikan told this story of the origin of his people in Klawock:

The people were on the other island. Lots of salmon were there. The people were killing the fish for fun--just to be killing them. Someone came, sent by the Raven, who told them that the Raven was tired of this and wanted no more of it. Only one women and her brother believed him. This woman went across the island to Prince of Wales, with her brother on her back. Behind her she could hear the waves and the people screaming. The woman was the beginning of the Klawock people. She was my grandparents' grandmother or great grandmother. ${ }^{2}$

My grandmother used to teach me these stories, but my grandfather told her not to. My grandfather said that I had to learn to live in the world as it is today.

One Haida girl had a sister whose name is the longest word in

Haida. The girl related:

. . Her name (my sister's) means there is a peacock at the end of a stream in a tree. The tree had two heads (two tops) and the peacock is in a big nest made of twigs trying to break open an abalone shell to get the meat.

${ }^{1}$ Edward L. Keithahn, op. cit., p. 148.

2 Each lineage group had its own story of its beginning. Note that both of the respondents quoted referred to the relative in relation to another relative--not to "my great great grandmother" or "my great grandfather"; but my "grandparents' great grandmother" and "my uncle's great grandfather", using descriptive terms for primary denotative terms. George Peter Murdock discusses this in "Kinship and Social Behavior Among the Haida," American Anthropologist (1934), p. 384. 
The girl continued:

Do you know about the akustika or gogaet? The gogaet grow from the little ones who are lost in the woods.

- . They eat fish and some say that there are fish bones sticking out all over their faces but I doubt this. I think maybe their faces get all hairy as they grow older. It's mercy to kill them. My uncle tells about the old man sitting by the fire who watched the gogaet get closer and closer and then the old man shot the gogaet. He ran and was found caught in the branches in the woods. I like all my uncle's stories because they are true about my people.

My name means "dusk on the maid." This was my uncle's great grandmother's name.

. . Did you know that my mother and one of her sisters were princesses? (My mother's generation) didn't have slaves because it was the beginning of civilization, and they didn't wear beads.

This girl, who had been using slang as she talked, calling the probation officer "what's her face" and her mother "my old lady" relaxed as she talked about her people. This child, who tried so hard to give me the impression of brittleness, was only 14 . She was 12 when she was first placed in detention. She is round, roundeyed, round-faced, and seems stocky although she has a little waist. Her fingers and hands are delicate. Her eyes are almost black; her skin bronzed by the sun. Her black hair is straight.

One of the boys said that he didn't believe in the old time legends the way his older brother did. The boy knew one story he liked particularly about "the akustika, one-half land otter and onehalf man who is so strong that it can swim one or two miles out 
into the ocean to a boat."

\section{Activities}

The almost universal concern for themselves and their peers was the drinking. The category "dances or parties" should have been two categories, many respondents said. There is a distinction between going to a dance and to a "party." The definition of "party" is a gathering of young people to drink.

The respondents of the study group go to the Northland or "walk around and walk around" alone. The other respondents varied where they went. None use the Civic Center anymore. They said, 'It's for little kids."

One basketball player of the control group described his present group:

This group plays basketball. They get decent grades and are in with the teachers. We all want to go on to school but don't know if we're capable. Some like me, were in with the "crowd" and left it. I still have friends in the crowd and speak to them. I got in the crowd in the first place because although all my life I'd played with the good group, when I went fishing with my dad a couple of summers, when I got back I was out; and so then I starting hanging around the Northland and got in with the "in-group."

He also said, "These kids are even down on the ones that go to Wasilla and places like that. "1

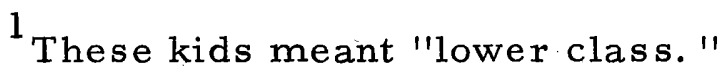


Comprehensiveness was sacrificed for reliability, and the responses to the questionnaire took priority over the information from the interviews and the records. Further analysis, statistically, is undertaken in Chapter $\mathrm{V}$ which presents the findings about the significance of the differences among categories. 


\section{CHAPTER V}

\section{FINDINGS}

This study was concerned with subjective responses of selected experiences in the boys' and girls' lives in the community. These experiences were reflected in the respondents' self-reports about their delinquent behavior, their report of friends'behavior and their report of anticipated delinquent behavior; their attitude toward community norms of education and occupation; their known delinquent friends; their perception of community's reaction to deviance with respect to four groups of significant persons: parents, neighbors, police and friends; the respondents' integration into their neighborhood; and their activities participated in and with whom. If the selfreports of the two groups were significantly different it was as sumed their experiences had been significantly different. This difference would reflect that the two groups had brought varied feelings and actions to the community as well as that the community had reacted with varied feelings and actions.

Guide line null hypotheses were formed with respect to each of the items in the six classifications. To determine whether the null hypotheses could be accepted or rejected, the totals of the responses 
were grouped into intervals large enough to meet the chi-square minimal requirement of five theoretical frequencies in a cell. The 5 per cent probability level was used. With one degree of freedom, the critical value is $3.841 .^{1}$ With two degrees of freedom, this is 5. $991 .^{2}$ At times the differences in the responses were evident by inspection. Percentages were also used in comparing the two groups' responses.

\section{REPORT OF DELINQUENT BEHAVIOR}

\section{$\underline{\text { Self-Report }}$}

The null hypothesis established was that there are no significant differences in the responses of the study group and the control group with respect to the nine items of the self-report scale. The null hypothesis was accepted for the items in Table XII and rejected for the items in Table XIII. The null hypothesis was rejected with reference to the totals of all the acts for all nine items: $X^{2}=15.8$ with two degrees of freedom. A greater proportion of the study group admitted committing these acts--and more frequently--than of the control group as is shown in Table $\mathrm{XV}$.

${ }^{1}$ Herbert Arkin and Raymond R. Colton, Tables for Statisticians (New York: Barnes and Noble, Inc., 1950, 1963, 1966), p. 126 .

Ibid. 
TABLE XII

CATEGORIES IN WHICH THE RESPONSES OF THE TWO GROUPS

ABOUT SELF-REPORTED DELINQUENT BEHAVIOR

WERE NOT SIGNIFICANTLY DIFFERENT

QUESTION 1:

The Behavior

$\mathrm{x}^{2} .05$

a. Had driven a Honda without a license

.2685

b. Had driven a car without a license

.331

c. Had taken little things

.0167

i. Had damaged things

1.1878

k. Had threatened another kid for money

By inspection

One degree of freedom throüghout.

The differences were in responses about acts that, if committed by an adult would not have been a major offense or a felony. Two of the behaviors dealt with attitudes toward parents and home, disobeying parents to their faces or running away, and the third behavior was about drinking. These responses indicated that the group came from the poverty level and that the community's status values had given them little opportunity to develop pride in their families; they were ashamed of their families or ashamed of themselves in their families. One of the girls said that she thought that her family had low status in the community--and that it had had low status in the olden days too. One of the boys said about his parents, "They are just like all of us--all right until they start drinking. " 
TABLE XIII

CATEGORIES IN WHICH THE RESPONSES OF THE TWO GROUPS

ABOUT SELF-REPORTED DELINQUENT BEHAVIOR WERE SIGNIFICANTLY DIFFERENT

QUESTION 1:

c. Had disobeyed parents' authority

By inspection

e. Had been drinking

f. Had run away from home

By inspection

By: inspection

One degree of freedom throughout.

TABLE XIV

CATEGORIES IN WHICH THE SIGNIFICANCE OF THE DIFFERENCE OF THE RESPONSES OF THE TWO GROUPS ABOUT

SELF - REPORTED BEHAVIOR COULD NOT

BE DETERMINED*

QUESTION 1:

The Behavior

$x^{2} \cdot 05$

Had beat up kids or adults

*cell $\mathrm{n}$ insufficient

Table XV gives the percentages of the responses of each group for each item. 


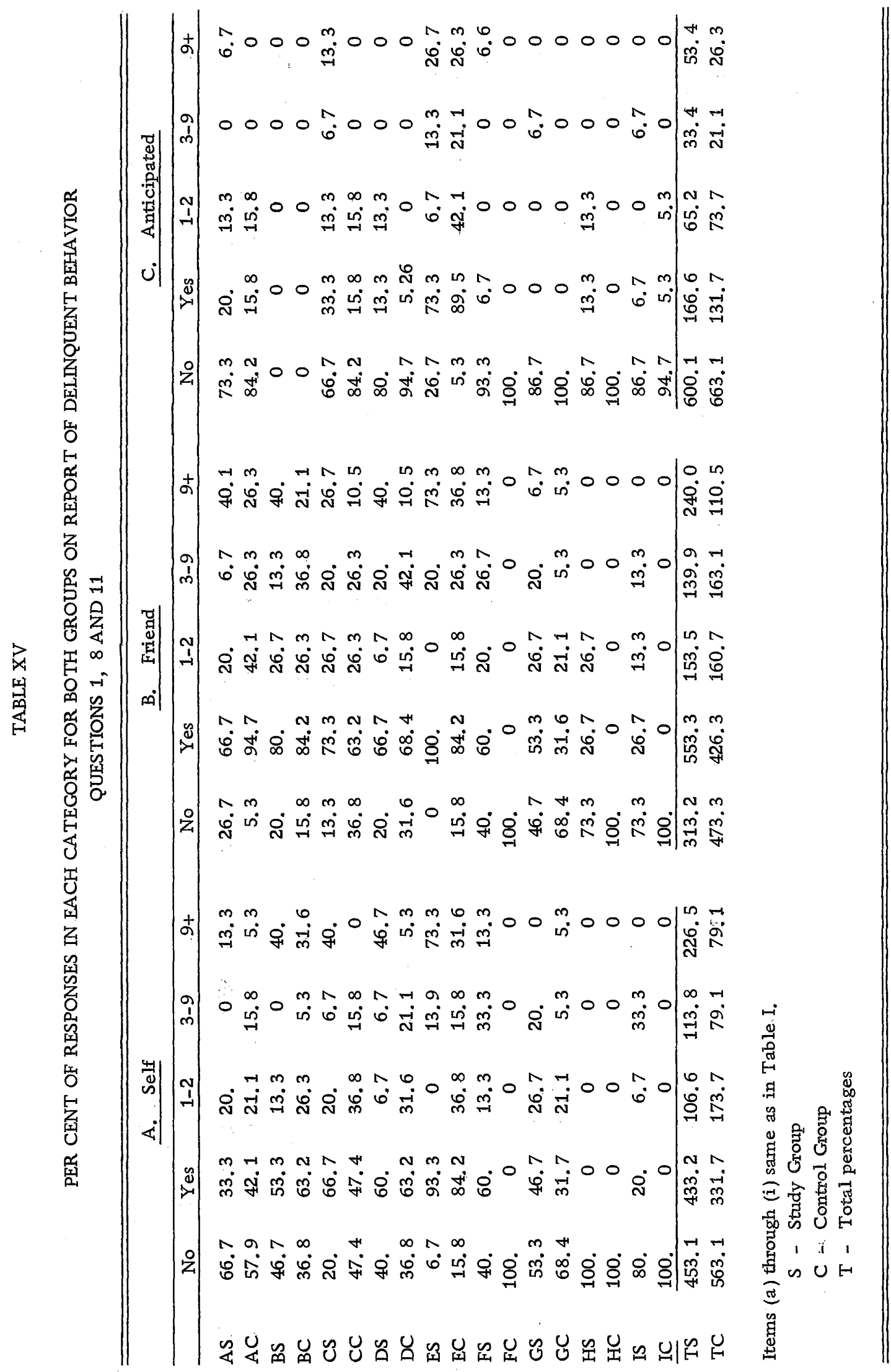


$\underline{\text { Report of Friends' Behavior }}$

The null hypothesis established was that there are no significant differences in the responses of the two groups with regard to the report of behavior of friends. Table XVI shows that there are more categories in which the behavior of friends was reported with no significant differences compared with self-reports as shown in Table XII.

TABLE XVI

CATEGORIES IN WHICH THE RESPONSES OF THE TWO GROUPS ABOUT FRIENDS' DELINQUENT BEHAVIOR WERE NOT SIGNIFICANT LY DIFFERENT QUESTION $8::$

a. Had driven a Honda without a license

b. Had driven a car without a license

c. Had disobeyed their parents

d. Had taken little things

h. Had threatened other people for money

i. Had beat up other kids or adults
By inspection By inspection .9173 .8935

By inspection By inspection

One degree of freedom throughout.

Table XVII shows that there are significant differences about two of the same acts as were noted in self-reports and one additional act. There is also a significant difference in the number of times friends had committed the total number of acts. 
TABLE XVII

CATEGORIES IN WHICH THE RESPONSES OF THE TWO GROUPS ABOUT FRIENDS' DELINQUENT BEHAVIOR

WERE SIGNIFICANT LY DIFFERENT

QUESTION 8:

The Behavior

e. Had been drinking

g. Had damaged things that did not belong to them

f. Had run away from home $x^{2} \cdot 05$

By inspection

By inspection

By inspection

Total number of times friends had committed total number of acts:

6.1926

One degree of freedom throughout

Table XV shows that a greater proportion of the study group reported having friends' committing the acts--and more frequently-than the control group.

Tables XVIII and XIX show that each group's self-report scale and report of friends' behavior about items (b) through (i) were not significantly different. Each groups' self-report of item (a) was significantly different by inspection from report of friends' behavior. 
TABLE XVIII

CATEGORIES IN THE GROUPS' SELF-REPORT AND THE GROUPS' REPORT OF FRIENDS' BEHAVIOR IN WHICH THERE WERE NO SIGNIFICANT DIFFERENCES

QUESTIONS 1 AND 8:

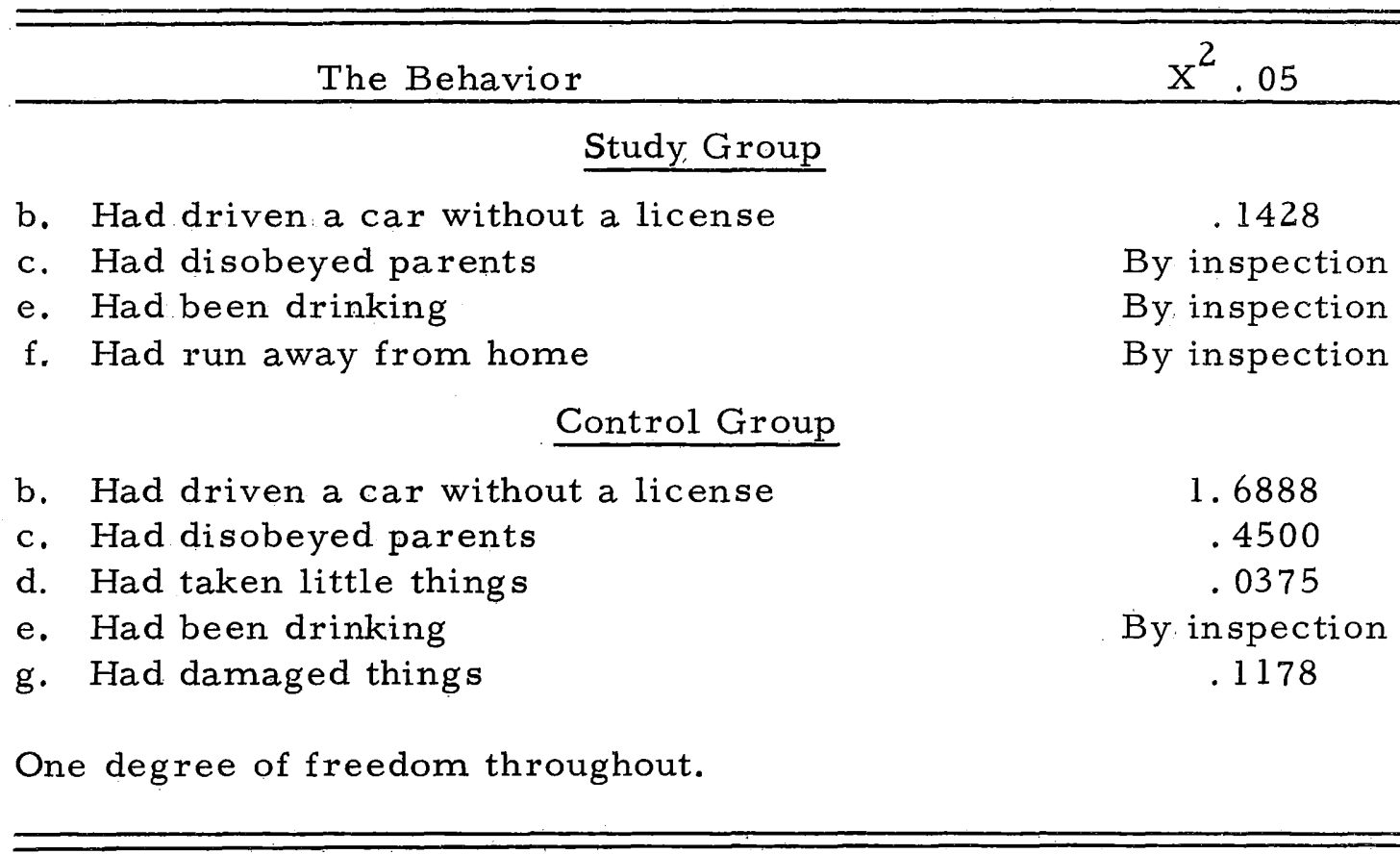


TABLE XIX

THE SIGNIFICANCE OF THE DIFFERENCE OF CATEGORIES IN WHICH THE GROUPS' SELF-REPORT AND THE GROUPS'

REPORT OF FRIENDS' BEHAVIOR COULD

NOT BE DETERMINED

QUESTIONS 1 AND 8:

The Behavior

\section{Study Group}

d. Had taken little things

g. Had damaged things

h. Had threatened another person for money

i. Had beat up other persons

Control Group

h. Had threatened another person for money

i. Had beat up another person

The high correlation between reports of own behavior and reports of friends' behavior suggests that the behavior is group phenomena. It at least does not rule out that it is group phenomena. Both groups were more objective about friends. They both reported friends' committing these acts more frequently than themselves.

\section{$\underline{\text { Anticipated Behavior }}$}

The null hypothesis established was that there are no significant differences in the two groups' responses with respect to their anticipated behavior. The significance of the differences in the 
responses could not be determined. Neither group had members who anticipated as many of the actions in the future as they had committed. Table XV shows that more of the study group anticipated this behavior than that of the control group, except that 20 per cent more of the control group anticipated drinking in the future. The same percentage of each group, 26 per cent, expected to drink nine or more times.

The lack of correlation between self-reported behavior and anticipated behavior could be due to the age of these respondents. One respondent of the control group said: "They all go through it. Some get caught. Some grow out of it. . . It's like tight pants-you grow out of it."

One point of interest is that, although both groups anticipated drinking, during the summer and winter of 1967 only the study group had violations related to drinking. This indicates that there is a difference in some other variable, such as the place in which the individuals drink, the way they drink or a difference in the way the delinquency control system responds to them. Drinking was one of the factors in all violations of the study group, following release into the community, except for one respondent. One member of the control group said that the kids who got caught drinking were the ones who had to go down town to show off that they were drinking.

There was a preponderance of natives in the groups. Because 
of this and because drinking was correlated with most of the offenses, one wonders whether or not the original liquor laws with their discrimination against the native group have affected drinking patterns.

Lemert ${ }^{1}$ and Hawthorn, Jamieson and Belshaw, in The Indians of British Columbia ${ }^{2}$ speculate on the effect the original laws may have had on drinking patterns. Drinking is one stimulant used which tends to make the user aggressive. ${ }^{3}$ It may be that the respondents in the study group, with their apparent feeling of submissiveness and self-worthlessness, used the alcohol as a stimulant to increase their feeling of worth.

\section{ATTITUDE TOWARD COMMUNITY NORMS}

The null hypotheses established with respect to the two groups' attitude toward community norms were:

Hypothesis I. There are no significant differences in the responses of the study group and the control group with respect to

${ }^{1}$ Edwin M. Lemert, Alcohol and the North Coast Indian (Berkley and Los Angeles: University of California Press, 1954).

${ }^{2}$ Hawthorn, Jamieson and Belshaw, The Indians of British Columbia (Berkley: University of California Press and University of British Columbia, 1958).

3"Round-Up of Current Research: The Varieties of Drug Experience, "Trans-Action (St. Louis, Missouri: Washington University, October, 1968), p. 5. 
their perceptions of community norms, aspirations and expectations of educational and occupational attainment.

Hypothesis II. There are no significant differences in the responses of each group with respect to its perceptions of community norms, aspirations and expectations of educational and occupational attainment.

There are no significant differences in the two groups' perceptions of educational attainment; $\mathrm{x}^{2}=.3310$. There are significant differences by inspection of educational expectations. Both groups perceived the community norms of educational attainment as high school graduation or more, with one exception each. As Table XX shows a slightly higher percentage of the study group than the control group, 46.66 per cent of the study group as compared with 36.8 per cent of the control group perceived the community norm as some college, vocational school or college graduation.

When the responses are combined into the two classes of more than high school graduation and high school graduation and less, the hypothesis that there are no significant differences in each group's perceptions, aspiration, and expectations of educational attainment is accepted only with regard to the study group's perceptions and aspirations. Then $\mathrm{X}^{2}=2.4$. Table $\mathrm{XX}$ shows that of the study group only 6.66 per cent perceived the community norm as less than high school graduation, but 20 per cent aspired to less than high 
school graduation, and 52. 22 per cent expected never to finish high school. Table XX also shows that only one person, 5. 26 per cent of the control group, perceived the norm as less than high school, and that same person, 5. 26 per cent of the group, aspired and expected to achieve less than high school graduation. Of the control group 36.80 per cent saw the community norm as more than high school graduation, yet 89.40 per cent aspired to more than high school graduation, and 73.66 per cent expected to achieve more than high school graduation. In other words, the control group expected to go farther in educational attainment than it felt the community expected of it.

TABLE XX

PER CENTAGE OF RESPONSES OF THE TWO GROUPS WITH REGARD TO PERCEPTION OF COMMUNITY NORMS, ASPIRATIONS AND EXPECTATIONS OF EDUCATIONAL ACHIEVEMENT QUESTIONS 2, 3, AND 4:

\begin{tabular}{lccccccc}
\hline & \multicolumn{2}{c}{ Perception } & \multicolumn{2}{c}{ Aspiration } & \multicolumn{2}{c}{ Expectation } \\
& SG & CG & SG & CG & \multicolumn{1}{c}{ SG } & CG \\
\hline 8th & 0 & 0 & 0 & 0 & 6.66 & 0 \\
9th to llth & 6.66 & 5.26 & 20 & 5.26 & 46.66 & 5.26 \\
Senior High & 46.66 & 57.89 & 33.33 & 5.26 & 26.66 & 21.05 \\
Community College & 0 & 5.26 & 0 & 21.05 & 0 & 10.52 \\
1 or 2 years college & 13.33 & 15.78 & 13.33 & 21.05 & 0 & 15.78 \\
Vocational School & 6.66 & 0 & 6.66 & 15.78 & 0 & 21.05 \\
4 years college or & & & & & & \\
$\quad$ more & 26.66 & 15.78 & 26.66 & 31.57 & 20.00 & 26.31 \\
SG - Study Group & & & & & & & \\
CG-Control Group & & & & & & \\
\hline
\end{tabular}


TABLE XXI

\section{CATEGORIES IN WHICH THERE WERE SIGNIFICANT \\ DIFFERENCES IN THE RESPONSES OF THE \\ CONTROL GROUP IN ATTITUDES ABOUT \\ COMMUNITY NORMS OF EDUCATIONAL \\ ACHIEVEMENT \\ QUESTIONS 2, 3, AND 4:}

\begin{tabular}{lr}
\hline \multicolumn{1}{c}{ Attitudes } & $\mathrm{x}^{2} .05$ \\
\hline Perceptions/Aspirations & 11.3094 \\
Perceptions/Expectations & 5.2158 \\
One degree of freedom throughout. & \\
\hline
\end{tabular}

The records indicated that the expectations of the respondents realistic and correlated with their actual school placement. ${ }^{1}$

The significance of the differences with respect to the two groups' perceptions of community norms, aspirations and expectations of occupational attainment could not be determined. Both groups had difficulties with the questions designed to test those variables. The staff of the Atlantic Street Center also had reported this. They thought it might be because of the youth of their respondents. The respondents in my study group were older adolescents. As I observed the respondents' reactions and talked to them about the question, I felt the format was difficult for them. Second,

${ }^{1}$ See pp. 66-68. 
occupations listed didn't seem meaningful to them.

\section{DELINQUENT FRIENDS}

There were significant differences in the number of young people each group knew who had been in trouble and in court as is shown in Tables XXII and XXIII. Since the respondents of the study group had all been in correctional school they of course knew more young people who had been in court and in trouble. A question about how many young people they had known who had not been in trouble would have told more.

\section{TABLE XXII}

CATEGORIES IN WHICH THERE WERE SIGNIFICANT DIFFERENCES IN RESPECT TO THE NUMBER OF YOUNG PEOPLE EACH GROUP KNEW WHO HAD BEEN IN TROUBLE QUESTIONS 9 AND 10:

Number of young people known who had been in trouble.

Number of young people known who had been in court.

One degree of freedom throughout. 
TABLE XXIII

PERCENTAGE OF NUMBER OF RESPONSES ABOUT NUMBER OF YOUNG PEOPLE KNOWN WHO HAD BEEN

IN TROUBLE OR IN COURT

QUESTIONS 9 AND 10:

\begin{tabular}{|c|c|c|c|c|c|}
\hline \multirow[b]{2}{*}{ Category } & \multicolumn{5}{|c|}{ Percentage of Number of Young People } \\
\hline & None & $1-2$ & $3-5$ & $6-10$ & $\begin{array}{c}\text { More } \\
\operatorname{than} 10\end{array}$ \\
\hline \multicolumn{6}{|c|}{$\begin{array}{l}\text { Number of young people } \\
\text { known who had been in } \\
\text { trouble: }\end{array}$} \\
\hline SG & 0 & 13.33 & 0 & 6.66 & 86.66 \\
\hline CG & 15.78 & 10.52 & 5.26 & 26.31 & 42. 10 \\
\hline \multicolumn{6}{|c|}{$\begin{array}{l}\text { Number of young people } \\
\text { known who had been in } \\
\text { court: }\end{array}$} \\
\hline $\begin{array}{l}\text { SG } \\
\mathrm{CG}\end{array}$ & $\begin{array}{c}0 \\
10.52\end{array}$ & $\begin{array}{r}6.66 \\
21.05\end{array}$ & $\begin{array}{l}20 . \\
36.84\end{array}$ & $\begin{array}{r}13.33 \\
5.26\end{array}$ & $\begin{array}{l}60 . \\
26.31\end{array}$ \\
\hline \multicolumn{6}{|c|}{$\begin{array}{l}S G-\text { Study Group - } N=15 \\
C G-\text { Control Group - N = } 19\end{array}$} \\
\hline
\end{tabular}

The fact that delinquent behavior is a group phenomena has again not been ruled out.

IV. PERCEPTION OF COMMUNITY REACTION TO DEVIANCE

The significance of the difference in the two groups' responses about perception of community reaction to deviance could in most instances, not be determined because of the smallness of the 
number, less than five, in at least one of the categories to be used in the four cells. Tables XXIV and XXV show this. Table XXVI gives the percentages of responses.

TABLE XXIV

CATEGORIES IN WHICH THE RESPONSES OF THE TWO GROUPS ABOUT LIKELIHOOD OF DISCOVERY OF MISBEHAVIOR WERE NOT SIGNIFICANTLY DIFFERENT QUESTIONS 12, 13, 14, AND 15:

Significant Person $\quad x^{2} .05$

Police finding out about behavior

1.6279

One degree of freedom.

TABLE XXV

CATEGORIES IN WHICH THE SIGNIFICANCE OF DIFFERENCE ABOUT LIKELIHOOD OF DISCOVERY COULD NOT BE DETERMINED QUESTIONS 12, 13, 14, AND 15:

Significant Person

Parents finding out about behavior

Neighbors finding out about behavior

Friends finding out about behavior 
TABLE XXVI

PERCENTAGE OF RESPONSES OF THE TWO GROUPS WITH

RESPECT TO LIKELIHOOD OF

DISCOVERY OF MISBEHAVIOR

QUESTIONS 12, 13, 14, 15:

\begin{tabular}{|c|c|c|c|c|}
\hline $\begin{array}{l}\text { Significant } \\
\text { Person }\end{array}$ & $\begin{array}{c}\text { Very } \\
\text { Unlikely } \\
\end{array}$ & Unlikely & Likely & $\begin{array}{l}\text { Very } \\
\text { Likely }\end{array}$ \\
\hline \multicolumn{5}{|l|}{ Parents } \\
\hline SG & 0 & 13.33 & 46.66 & 40. \\
\hline CG & 10.52 & 5.26 & 21.05 & 52.63 \\
\hline \multicolumn{5}{|l|}{ Neighbors } \\
\hline SG & 6.66 & 26.66 & 60. & 6.66 \\
\hline CG & 10. 52 & 10.52 & 42. 10 & 36.84 \\
\hline \multicolumn{5}{|l|}{ Friends } \\
\hline SG & 0 & 5.26 & 46.66 & 46.66 \\
\hline CG & 5.26 & 0 & 26.31 & 68.42 \\
\hline \multicolumn{5}{|l|}{ Police } \\
\hline SG & 13.33 & 40. & 33.33 & 13.33 \\
\hline CG & 10.52 & 21.05 & 42.10 & 26.31 \\
\hline \multicolumn{5}{|c|}{$\begin{array}{l}\text { SG - Study Group - N = } 15 \\
\text { CG - Control Group }-N=19\end{array}$} \\
\hline
\end{tabular}

Table XXVII and XXVIII show the findings with respect to the respondents' perception of likelihood of punishment. A greater proportion of the control group, 84 per cent, thought their parents would punish for misbehavior, but over 50 per cent of the study group thought parents would punish. Of the study group, 100 per cent thought it likely or very likely that the police would do something about the respondents' behavior, while 84 per cent of the 
control group thought so. Two of the three of the control group who thought the police would not do anything about the respondents' behavior were Caucasian. About 75 per cent of both groups thought that friends would do nothing about respondents' behavior. These responses again point the way toward the group phenomena of behavior of young people this age. The responses also indicate that the control group felt surer of parental control than did the study group.

TABLE XXVII

CATEGORIES IN WHICH THE RESPONSES OF THE TWO GROUPS ABOUT LIKELIHOOD OF PUNISHMENT WERE NOT SIGNIFICANTLY DIFFERENT QUESTIONS 16, 17, 18, AND 19:

\begin{tabular}{lc}
\hline \multicolumn{1}{c}{ Significant Person } & $\mathrm{x}^{2} \cdot 05$ \\
\hline Parents' punishing them & 3.8257 \\
Neighbors' doing something about the behavior & 1.2004 \\
One degree of freedom throughout. & \\
\hline
\end{tabular}


TABLE XXVIII

PERCENTAGE OF RESPONSES OF THE TWO GROUPS WITH RESPECT TO LIKELIHOOD OF PUNISHMENT

QUESTIONS 16,17,18, AND 19:

\begin{tabular}{|c|c|c|c|c|}
\hline $\begin{array}{c}\text { Significant } \\
\text { Person } \\
\end{array}$ & $\begin{array}{c}\text { Very } \\
\text { Unlikely } \\
\end{array}$ & Unlikely & Likely & $\begin{array}{r}\text { Very } \\
\text { Likely } \\
\end{array}$ \\
\hline \multicolumn{5}{|l|}{ Parents } \\
\hline $\mathrm{SG}$ & 13.33 & 33.33 & 26.66 & 26.66 \\
\hline $\mathrm{CG}$ & 5.26 & 10.52 & 42. 10 & 42.10 \\
\hline \multicolumn{5}{|l|}{ Police } \\
\hline $\mathrm{SG}$ & 0 & 0 & 26.66 & 73.33 \\
\hline CG & 10.52 & 5.26 & 42. 10 & 42.10 \\
\hline \multicolumn{5}{|l|}{ Neighbors } \\
\hline $\mathrm{SG}$ & 13.33 & 53.33 & 20. & 6.66 \\
\hline CG & 10.52 & 42. 10 & 31.57 & 15.78 \\
\hline \multicolumn{5}{|l|}{ Friends } \\
\hline SG & 46.66 & 33.33 & 20. & 0 \\
\hline CG & 52.63 & 21.05 & 15.78 & 10.52 \\
\hline \multicolumn{5}{|c|}{$\begin{array}{l}\text { SG - Study Group - N = } 15 \\
\text { CG - Control Group - N }=19\end{array}$} \\
\hline
\end{tabular}

The responses seem to be consistently related inversely.

\section{INTEGRATION IN NEIGHBORHOOD}

The significance of the difference in the responses about this variable could not be determined. Table XXIX shows that 47 per cent of the study group liked the neighborhood in which its members lived, while 84 per cent of the control group liked the neighborhood. 
Both groups had close friends in respondents' neighborhood and in their school, and a little more than 50 per cent of both groups had close friends who ran around together in a group.

\section{TABLE XXIX}

PERCENTAGE OF RESPONSES OF BOTH GROUPS ABOUT INTEGRATION IN NEIGHBORHOOD

QUESTIONS 20, 21, 22, AND 23:

\begin{tabular}{ccccc}
\hline & Not at & Not & & Very \\
Category & all & very much & Somewhat & much \\
\hline
\end{tabular}

Do you like the neighborhood in which you live?
SG
20.
26.66
46.66
6.66
CG
5.26
10.52
47.36
36.84

Close friends in the neighborhood:

\begin{tabular}{lrl}
$\frac{0-3}{40 .}$ & $\frac{4-7}{43}$ & \multicolumn{1}{c}{. } \\
63.16 & 13.33 & 40. \\
& 5.26 & 21.05
\end{tabular}

SG

$\mathrm{CG}$

Close friends who go

to your school:

SG

6.66

20.

73.33

CG

5. 26

21. 05

68.42

Close friends in group:

SG

40.

20.

33.33

$\mathrm{CG}$

36.84

36.84

21. 05

SG - Study Group - N $=15$

CG - Control Group - N = 19 


\section{VI. . ACTIVITIES}

The null hypotheses were that there are no differences in the two groups' participation in certain activities and in who accompanied the respondents to those activities. Table XXX shows the differences in the responses of the two groups in percentages. Table XXXIII shows that there were no significant differences in participation in four of the activities. Table XXXIV shows that there were significant differences in participation in dances and parties, baseball and basketball.

Several of the respondents said that there should have been two categories: one, "dances, " and one, "parties;" the definition of "party is a gathering of youngsters to drink. There is a distinction between going to a dance and going to a party. Sometimes the parties followed the dances.

Baseball and basketball are both adult sponsored and organized recreational activities in Ketchikan for young people. In baseball there are Minor League, Little League, Babe Ruth and Young Adult baseball. In basketball there are church-sponsored basketball, school basketball and Metro League for Junior High and High school age youngsters who do not play in school basketball. The record showed that two of the boys in the control group were on the varsity team of the high school and one of the girls was drill team leader for three years. 


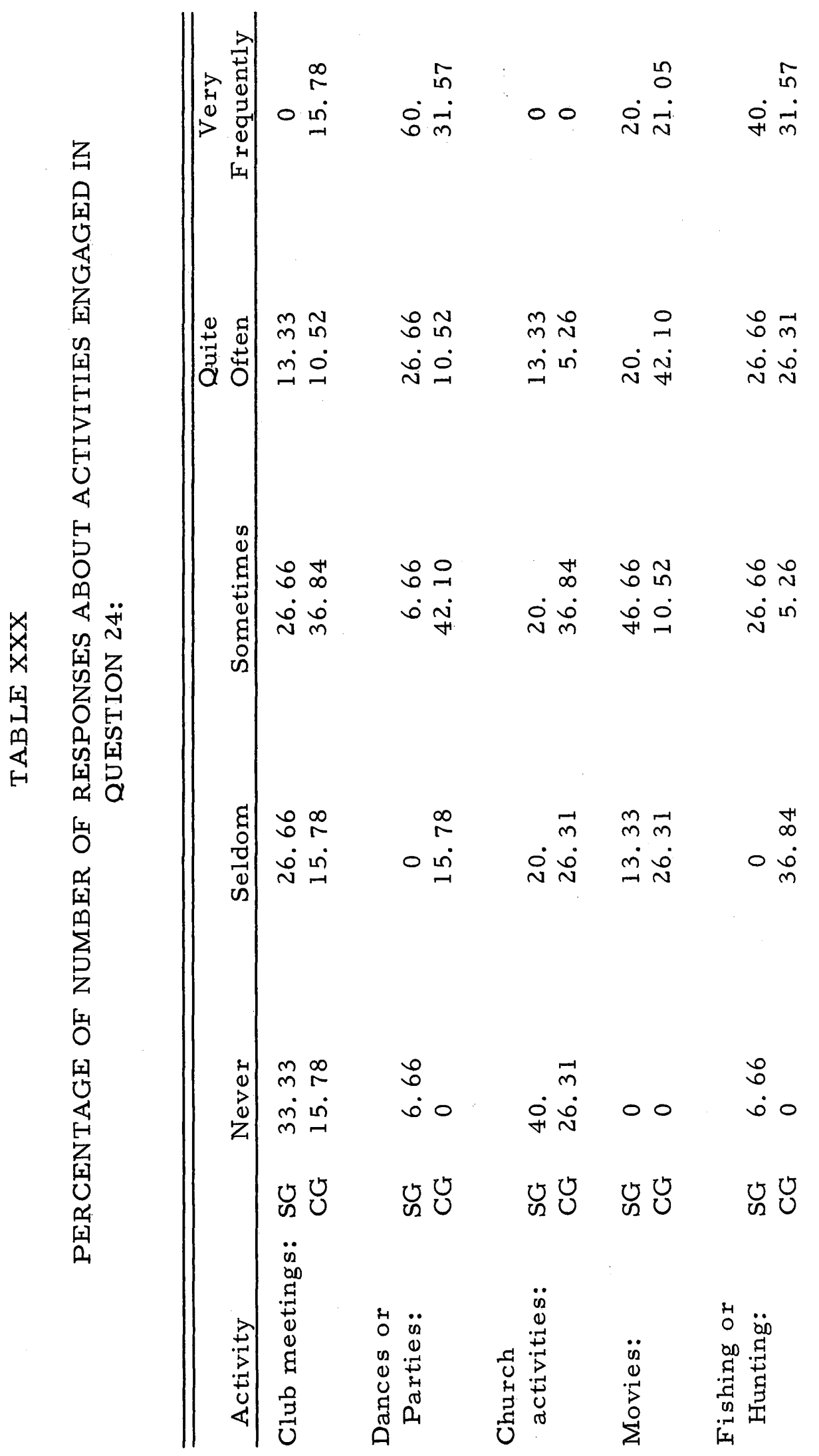




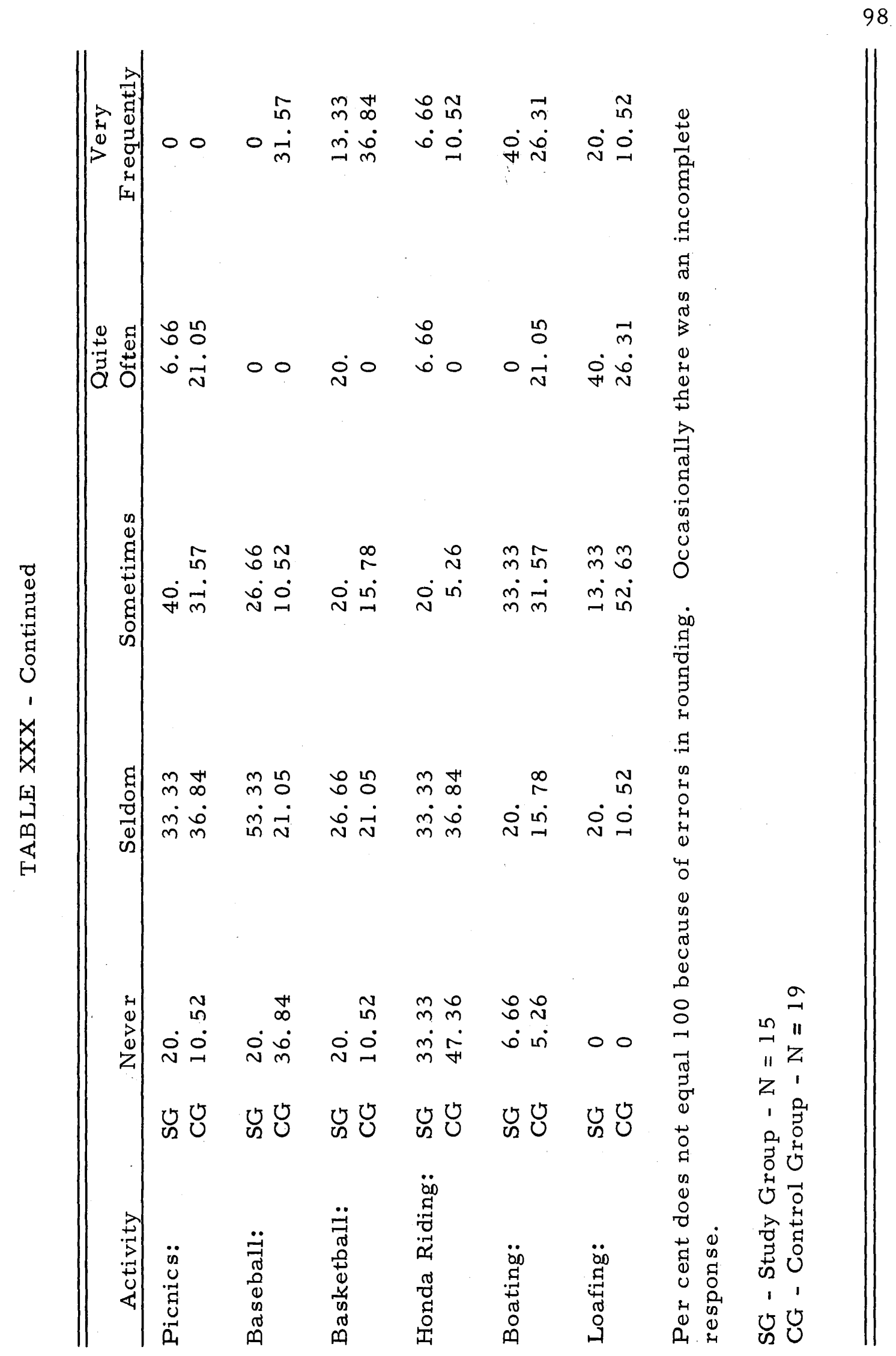


Table XXXII shows the difference in proportions as to who accompanied the respondents to activities. These results vary in relationship with totals shown in Table XXXI in two categories, sisters and other relatives. Otherwise the relationships of the totals are the same in both tables--showing the control group higher for companions in all categories except for no one and gang. Maybe members of the study group were more apt to be "loners" or with a "gang" than are the members of the control group. The members of the control group show that they considerable male identification. Having a father for a companion meet with community approval, but also means that the father is available to offer appropriate help is one is in trouble. 


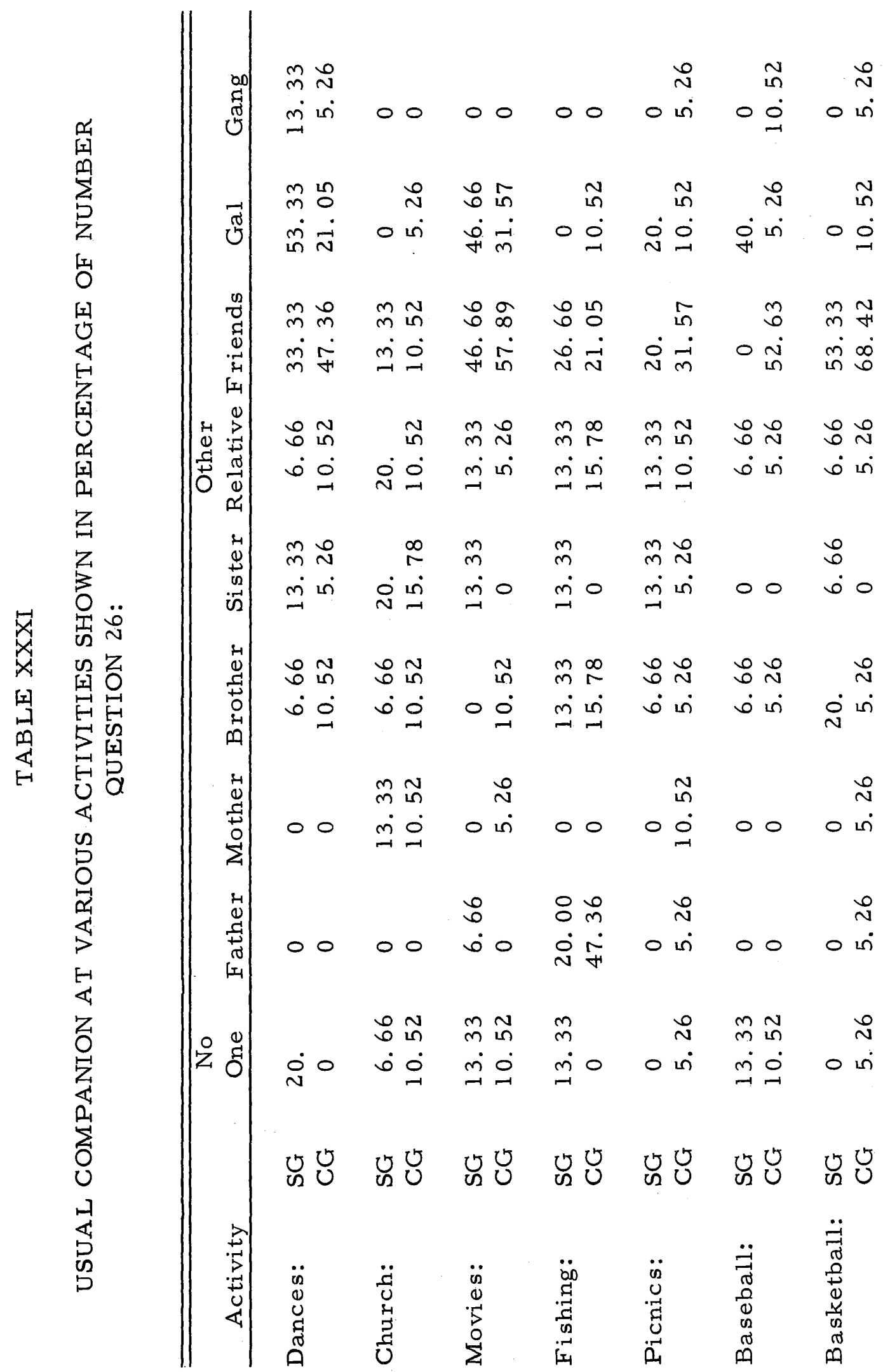




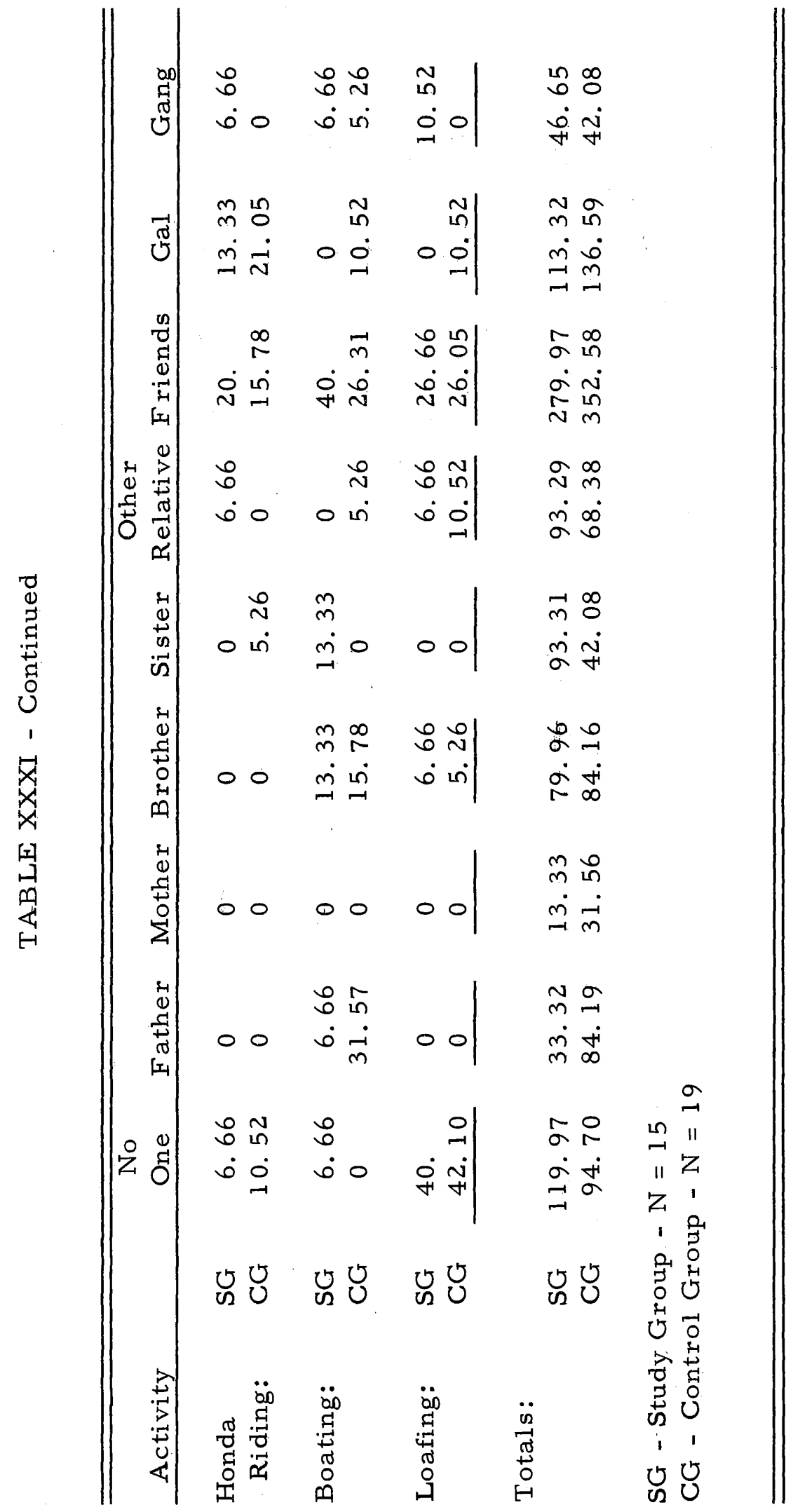


TABLE XXXII

USUAL COMPANION - SHOWN IN PERCENTAGE OF NUMBER QUESTION 25:

\begin{tabular}{lcc}
\hline & & \\
Companion & Study Group & Control Group \\
\hline No One & 33.33 & 21.05 \\
Father & 40. & 68.42 \\
Mother & 33.33 & 52.63 \\
Brother & 33.33 & 63.16 \\
Sister & 26.66 & 42.10 \\
Other Relative & 33.33 & 57.89 \\
Friends & 66.66 & 89.47 \\
Gal & 53.33 & 68.42 \\
Gang* & 46.66 & 42.10 \\
SG - Study Group - N = 15 & & \\
CG - Control Group - N = 19 & \\
*Difference not statistically significant & \\
- & \\
\hline
\end{tabular}


TABLE XXXIII

CATEGORIES IN WHICH THERE WERE NO SIGNIFICANT

DIFFERENCES IN PARTICIPATION IN

CERTAIN ACTIVITIES

\begin{tabular}{lc}
\hline \multicolumn{1}{c}{ Activity } & $\mathrm{X}^{2} .05$ \\
\hline Club activity & 1.7591 \\
Movies & .0507 \\
Boating & .1858 \\
Loafing & 2.4158 \\
One degree of freedom throughout. & .7001 \\
Totals of participation in all activities. \\
Three degrees of freedom for last item. \\
\hline
\end{tabular}

TABLE XXXIV

CATEGORIES IN WHICH THERE WERE SIGNIFICANT

DIFFERENCES IN PARTICIPATION IN

CERTAIN ACTIVITIES

\begin{tabular}{lc}
\hline \multicolumn{1}{c}{ Activity } & $\mathrm{X}^{2} \cdot 05$ \\
\hline & \\
Dances and parties & 7.0288 \\
Baseball & By inspection \\
Basketball & By inspection \\
One degree of freedom throughout. & \\
\hline
\end{tabular}




\section{SUMMARY}

The findings indicate both similarities and differences between young people designated as either normal or delinquent. Both groups were objective about friends, drank beer with different meaning and consequences for each group, thought they were expected to finish high school and expected punishment for misbehavior.

The releasees admitted more misbehavior, knew young people in similar circumstances and were more open in their defiance.

The average or normal youngsters liked their community better, had higher aspiration, expectations and attainments at school, play and work and the delinquency control system operated less harshly with them.

In Chapter VI, the Conclusion, I will evaluate the research project, summarize some of the findings, some of the things I suspect and make some suggestions regarding what can be done about them. 


\section{CHAPTER VI}

\section{CONCLUSIONS}

Both groups of the research study were small and therefore, no conclusions can be drawn from the findings to a larger population. The control group, while independently selected, was neither a random sample of a population nor strictly matched on a number of, variables which turned out to be significant. The chi-square test of significance helped in the interpretation of the findings, especially since the two groups were of different size.

Except for some offenses considered more serious, the youth are similar in both groups with respect to behavior designated as delinquent. The study group reported committing the acts more frequently. The more favored group is protected by place of delinquency, low visibility and community norms of reaction. Those not protected by their status, including family and economic, adjust their behavior and life patterns, tending to oppose, resist or reject the norms which have degraded them. Incarceration handicaps them by lowering their status in family and community making normal peer relationships more difficult, teaching them more sophisticated anti-social attitudes and abilities and putting them behind their age 
group, especially in school.

In this setting, conflicting cultures add to the confusion of young people seeking an identity. The large proportion of indigenous Alaskans in the study group and the history of the delinquency patterns point to race as being associated with delinquency in this area, as in other areas, and point to the phenomenon of delinquency as having something to do with how groups of people treat each other in a community. Delinquency also has something to do with the interrelationships of sub-groups. Any future study of this kind in Alaska might consider matching linguistic groups or nations and might also consider the effect of aboriginal status on the respondent's status today. Delinquency also has to do with one's relationships with one's own friends and gang.

The individual respondents of the study group were realistic in their perception of community norms. They were realistic too about their families' status in the town. It was of interest that the control group perceived the community's norms for education as lower than it aspired to.

Some points about the method itself might help others. The questionnaire was of interest to the respondents and easy for them to use, except for the question about employment. The questionnaire began too abruptly for use in a group setting without an interview first. If the responses in all multiple choices had been in the 
order from "0"" or "never" to the higher quantities, the responses could have been tabulated more easily. The quantification of the multiple choice replies in questions 19 through 23 would be more telling if they included " 0 " friend. There is a considerable difference between having " 0 " friend and "3" friends. One additional ques tion about number of friends and acquaintances who had not been known to the court and who had not been in trouble would make the questions about the number of friends known who had been in the court and in trouble more meaningful.

There is more that can be gleaned from the interviews, but comprehensiveness was sacrificed for reliability. Future research designed to yield reliable information from interviews and case his tories would be rewarding. The information from the interviews as well as the findings from the responses to the questionnaire challenged the notion that delinquency is a characteristic only of the person himself and also challenged the notion that our present system is geared for the good of the youthful offender. 
SOURCES CONSULTED

\section{BOOKS}

Amos, William E. and Wellford, Charles F. (ed.). Delinquency Prevention. Englewood Cliffs, New Jersey: Prentice-Hall, Inc., 1967,

Arkin, Herbert and Colton, Raymond R. Tables for Statisticians. New York: Barnes and Noble, Inc, 1966.

Balcom, Mary G. Ghost Towns of Alaska. Chicago: Adams Press, 1965.

Barbeau, Marius. Haida Carvers in Argillite. Bulletin \#139. Department of Northern Affairs and National Resources, National Museum of Canada. Queen's Printer and Controller of Stationery, Ottawa: Edmond Cloutier, C. M. G. , O. A. S. D. S. P. , 1957.

Cohen, Albert K. Deviance and Control. Englewood Cliff, New Jersey: Prentice-Hall, Inc., 1966.

Drucker, Phillip. Indians of the Northwest Coast. Garden City, New York: The Natural History Press, 1955.

Eissler, K. R. (ed.). Searchlights on Delinquency. New York: International Universities Press, 1965.

Erikson, Erik H. Insight and Responsibility. New York: W. W. Norton and Company, 1964.

Fyvel, T. R. Troublemakers. Rebellious Youth in an Affluent Society. New York: Schocken Books, 1966.

Garfield, Viola E., Wingert, Paul S., and Barbeau, Marius. The Tsimpshian: Their Arts and Music. Edited for the American Ethnological Society by Marian W. Smith. Vol. XVIII. New York: J. J. Augustin, Publisher, n. d. 
Giallombardo, Rose, (ed), Juvenile Delinquency: A Book of Readings. New York: John Wiley and Sons, Inc., 1966.

Gibbons, Don C, Changing the Lawbreaker, Englewood Cliffs, New Jersey: Prentice-Hall, Inc., 1965.

Gruening, Ernest, The State of Alaska. New York: Random House, 1954.

Hawthorn, Harry Betram, Belshaw, C. S. and Jamieson, S, M. The Indians of British Columbia. Berkeley: University of California Press and University of British Columbia, 1958.

Keithahn, Edward L. Monuments in Cedar, Ketchikan: Roy Anderson, 1945.

Konopka, Gisela, The Adolescent Girl in Conflict. Englewood Cliffs, New Jersey: Prentice-Hall, Inc., 1966.

Lander, Bernard, Towards an Understanding of Juvenile Delinquency. New York: Columbia University Press, 1954.

Lemert, Edwin M. Alcohol and the Northwest Coast Indian. Berkely and Los Angeles: University of California, 1954.

McLuhan, Marshall and Fiore, Quentin. The Medium is the Massage, New York: Bantam Books, Inc., 1967.

Moles, Oliver, Lippitt, Ronald, and Withey, Stephen. A Selective Review of Research and Theory on Delinquency. Institute for Social Research. Ann Arbor: The University of Michigan, 1959.

Polansky, Norman A, (ed.). Social Work Research. Chicago: University of Chicago Press, 1960.

Powers, Edwin and Witmer, Helen. An Experiment in the Prevention of Delinquency: The Cambridge-Sommerville Youth Study. New York: Columbia University Press, 1951.

Rogers, George W. The Future of Alaska. Baltimore: The Johns Hopkins Press, 1962.

Sanders, Virginia L. Measurement and Statistics. New York: Oxford University Press, 1958. 
Sellin, Thorsten (ed.). Juvenile Delinquency. Philadelphia: The Annals of the American Academy of Political and Social Science, 1949.

Sellin, Thorsten, and Wolfgang. The Measurement of Delinquency. New York: John Wiley and Son, Inc., 1964.

State and National Correctional Institutions of the United States of America, Canada, England and Scotland. Compiled by the American Correctional Association. Office of the General Secretary. New York: July, 1962.

Stouffer, Samuel A. Social Research and Test Ideas. New York: The Free Press of Glencoe, 1962.

Terrell, John Upton. The United States Department of Health, Education and Welfare. New York: Duell, Sloan and Pearce, 1965.

Wallis, W. Allen and Robers, Harry V. Statistics: A New Approach. Brooklyn, New York: The Free Press, 1956.

Weeks, H. Ashley. Youthful Offenders at Highfields. Ann Arbor: Ann Arbor Paperbacks, The University of Michigan Press, 1963.

Wherry, Joseph $\mathrm{H}$. The Totem Pole Indians. New York: Willard Funk, Inc., $19 \overline{64 .}$

Yablonsky, Lewis. The Violent Gang. Baltimore: Penguin Books, 1966.

\section{ARTICLES AND PERIODICALS}

Alaska's Health and Welfare. Vol, 19 (October, 1962), pp. 4-5. . Vol. 24 (June, 1967), pp. 14-16.

Beck, Bertram M., "The Exiled Delinquent," Children, Vol. 2, No. 6 (November-December, 1955), pp. 208-212.

. "Innovations in Combating Juvenile Delinquency," Children, Vol. 21, No. 2 (March-April, 1965), pp. 69-74.

Benyon, William. "The Tsimshians of Metlakatla, Alaska," American Anthropologist, Vol. 43 (1941), pp. 83-88. 
"Correction in the United States," Crime and Delinquency, Vol. 13 (January, 1967), p. 281.

De Laguna, Frederica. "Tlingit Ideas about the Individual," Southwestern Journal of Anthropology, Vol. 10 (1954), pp. 172 191.

Ellingston, John R. "Youth Authority and its Development in California," California Youth Authority Quarterly. Vol. 20 (1967).

Erikson, Erik. "Identity and the Life Cycle," Psychological Issues, Vol. 1, No. 1, Monograph. New York: International Universities Press, Inc. (1959), p. 171.

Garfield, Viola E. "Historical Aspects of Tlingit Clans in Angoon, Alaska," American Anthropologist, Vol. 49 (1947), pp. 438452.

Gold, Martin. "Undetected Delinquent Behavior," The Journal of Research in Crime and Delinquency, Vol. 3, No. 1 (January, 1966), pp. 27-46.

Lemert, Edwin. "On Alcoholism among the Northwest Coast Indians, " American Anthropologist, Vol. 58 (1958), pp. 561-2.

Lentz, William P. "Social Status and Attitudes toward Delinquency Control," The Journal of Research in Crime and Delinquency, Vol. 3, No. 2(July, 1966), pp. 147-154.

Murdock, George Peter. 'Kinship and Social Behavior among the Haida," American Anthropologist, Vol. 36 (1934), pp. 355383.

"Round-Up of Current Research: The Varieties of Drug Experience," Trans-Action, Vol. 5, No. 10 (October, 1968), p. 5. 


\section{ENGLISH-LANGUAGE DICTIONARIES}

The Random House Dictionary of the English Language. Unabridged Edition. New York: Random House, 1966-67.

Roget's International Thesaurus. 3rd Ed. New York: Thomas Y. Crowell Company, 1967 .

Webster's New Collegiate Dictionary. 6th Ed. Springfield, Mass.: G. and C. Merriam Company, 1967.

\section{GOVERNMENT PUBLICATIONS}

Alaska Housing. Authority. Comprehensive Plan, Ketchikan, Alaska. July, 1959.

Alaska Reporting Service Report 324. Department of Health and Welfare, June 26, 1967.

Blain, Daniel, M. D. Alaska Survey, Mental Health and Mental Retardation. State of Alaska. Juneau: Department of Health and Welfare, Division of Mental Health. September, 1964.

McDonald, J. Scott. Alaska State Plan for Construction of Mental Health Centers. Juneau: Department of Health and Welfare, 1968.

McNickle, Roma K. (ed). Differences that Make the Difference. Washington, D. C. : Commission on Correctional Manpower and Training, August, 1967.

The President's Commission on Law Enforcement and Administration of Justice. The Challenge of Crime in a Free Society, 1967. - Juvenile Delinquency and Youth Crime, 1967. - Task Force Report: Corrections, 1967.

U.S. Bureau of the Census. United States Census of Population. 1960. Alaska. Number of Inhabitants. 
- United States Census of Population. 1960.

Alaska. General Population Characteristics.

U. S. Senate. Juvenile Delinquency in the Territory of Alaska.

Report No. 2774, 84th Cong., 2d Sess., 1956.

Ure, Barbara, M. D. Comprehensive Mental Health Planning, 1963 64. State of Alaska. Governor's Committee, July, 1965.

\section{UNPUBLISHED MATERIAL}

DeJardin, Thomas et al. "The Assessment of Subjective Experiences of Boys Entering the Community from a Correctional School." Unpublished Master's thesis, School of Social Work, Portland State College, 1968.

Jameson, Samuel Haig and Sherman, Dorothy. A Report on the . Alaska Traveling Team. William T. Adams (ed.) Colorado: Western Interstate for Higher Education, 1964.

Marksheffel, Charles C. "A Survey of Gateway Borough School District, Ketchikan, Alaska," Written in partial fulfillment of requirements for Educational Specialist's Degree, Western State College of Colorado, 1964.

Northwest Regional Educational Laboratory, Program 200. "Education for Culturally Different Populations. " Working draft. Portland, Oregon, 1968. (Mimeographed)

Reilly, Francis J. "A Comparative Study of Indian and Non-Indian Parole Applicants in Alberta." Unpublished Master's thesis, St. Patrick's College, Ottawa, Ontario, 1967.

Seattle Atlantic Street Center. "Effectiveness of Social Work with Acting-Out Youth: Second Year Progress Report, September, 1963 - August, 1964. Seattle, 1964.

- "Third Year Progress Report, September, 1964August, 1965." Seattle, 1965.

. "Fourth Year Progress Report, September, 1965 - August, 1966." Seattle, 1966.

Simpson, Pam. "Eyak Indians." Written at Ketchikan High School, Ketchikan, Alaska, May 1, 1967. 
Tillotsen, Jan and Eleasser, Dennis. "Juvenile Delinquency: A Study. "Alaska Methodist University, February - August, 1966.

\section{OTHER SOURCES}

Abbott, William. Alaska State Jail, Ketchikan, Alaska. Interview. September 7, 1967.

Anderson, Keith. Alaska Youth and Adult Authority, Ketchikan, Alaska. Interview. September 6, 1968.

Gerde, Celeste. Chamber of Commerce, Ketchikan, Alaska. Interview. September 9, 1968.

Hackstock, Ray. Ketchikan Police Department, Ketchikan, Alaska. Reports for FBI Uniform Crime Reporting. September, 1967.

Hansen, Richard D. Gateway Borough Public School System. Letter. August 21, 1968.

Horn, Kermit. Alaska State Detention Home. Official records, July, 1966 - June, 1967. Interview. September 8, 1967.

Hunt, Nancy. Alaska State District Court, Ketchikan, Alaska. Interview. August 22, 1967.

Ketchikan Children's Home. Interview with child. February, 1955.

Ketchikan Pulp Company. Advertising Brochure. "The Story of Wood Pulp Manufacture in Southeastern Alaska. n.d.

Lauber, Richard B, Alaska State Division of Youth and Adult Authority, Juneau, Alaska. Letter. March 23, 1967.

McDaniel, Curtis. Alaska State Division of Youth and Adult Authority, Ketchikan, Alaska. July 13, 1967.

Murton, Tom. Tucker State Farm, Tucker, Arkansas. Letter. September 18, 1967.

Pinquoch, Wayne, Alcantra Youth Camp, Wasilla, Alaska. Letter. October 24, 1967. 
Simonsen, Arthur. Alaska State Superior Court, Ketchikan, Alaska. Interview. September 6, 1967.

Whitesides, Dale. Alaska Department of Highways, Ketchikan, Alaska. Interview. September 9, 1968. 


\begin{abstract}
APPENDIX
Recording Form

Number

Date

Time
\end{abstract}

Where contact was made.

Who made contact?

What was contact?

For example:

At the Probation Office, I read records.

At the boys' home, I interviewed

the boy and gave him the questionnaire. 
Number:

Date:

Place:

1. Have you ever done any of these things? Circle answer yes or no. If your answer is yes, circle answer how often.

Driven a motorcycle without a Yes No driver's license? If so, how often? $\begin{array}{llll}0 & 1-2 & 3-9 & \text { More than } 9\end{array}$

Driven a car without a driver's Yes No license? If so, how often? $01-2$ 3-9 More than 9

Disobeyed your parents' Yes No authority to their face? If so, how often?

$\begin{array}{llll}0 & 1-2 & 3-9 & \text { More than } 9\end{array}$

Taken little things that did not belong to you? If so, how often?

Yes No

$0 \quad 1-2 \quad 3-9 \quad$ More than 9

Bought or drunk beer, wine, or liquor (including drinking at home)? If so, how often?

Run away from home? If so, how often?

Yes No

$0 \quad 1-2 \quad 3-9 \quad$ More than 9

Yes No

$\begin{array}{llll}0 & 1-2 & 3-9 & \text { More than } 9\end{array}$

On purpose, damaged, or Yes No destroyed things that did not belong to you? If so, how often?

$0 \quad 1-2 \quad 3-9 \quad$ More than 9

Threatened another kid for money? If so, how often?

$\begin{array}{llll}\text { Yes } & \text { No } & \\ 0 & 1-2 & 3-9 & \text { More than } 9\end{array}$

Beat up kids or adults who Yes No haven't done anything to you? If so, how often?

$0 \quad 1-2 \quad 3-9 \quad$ More than 9


Number: Date: Place:

2. How far do you think most people would say a person should go in school before he
quits and begins working?

8th grade 9-1lth grade

Senior high school

Community college

3. How far do you yourself want to go in school?

$\begin{array}{ll}\text { A year or two } & \text { Vocational } \\ \text { of college } & \text { school } \\ \text { College ( } 4 \text { years or more) }\end{array}$

8th grade $\quad 9-11$ th grade

Senior high school

Community college

$\begin{array}{lr}\text { A year or two } & \text { Vocational } \\ \text { of college } & \text { school } \\ \text { College (4 years or more) }\end{array}$

4. How far do you think that you will actually get before you quit school?

8th grade $\quad 9-11$ th grade

Senior high school

Community college
A year or two
Vocational of college school
College (4 years or more)

5. Write the jobs on the rungs of the ladder, placing at the top the job that you think would lead to the most success and at the bottom the job that you think would be least successful. 
Number:

Date:

Place:

5. (continued)

The jobs are: Owner of a lunch stand

Manager of a grocery store

Accountant - bookkeeper

Owner of a manufacturing company

Electrician

Janitor

Physician (doctor)

(Pulp mill) Engineer

Truck Driver

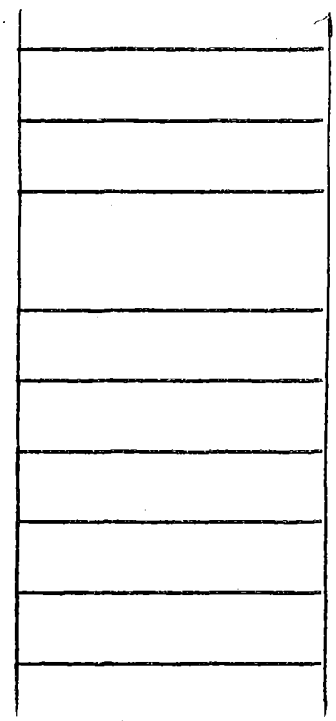

6. Now place those jobs on this ladder, placing the job that you would like best to have at the top and the one that you would like least to have at the bottom:

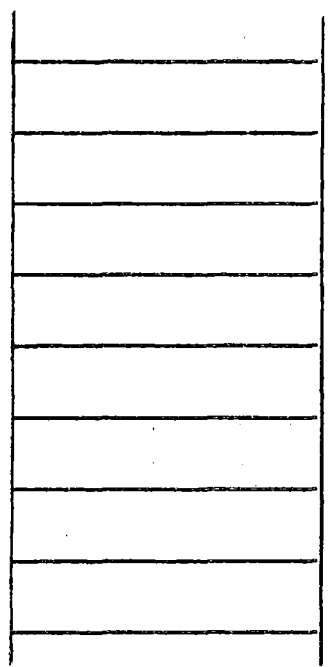

7. Place the jobs on the ladder, placing the job that you think you have the best chance of having at the top and the one that you think you have the least chance of having at the bottom. (This means your best chance of having it in a few years - not now). 
Number: Date: Place:

7. (continued)

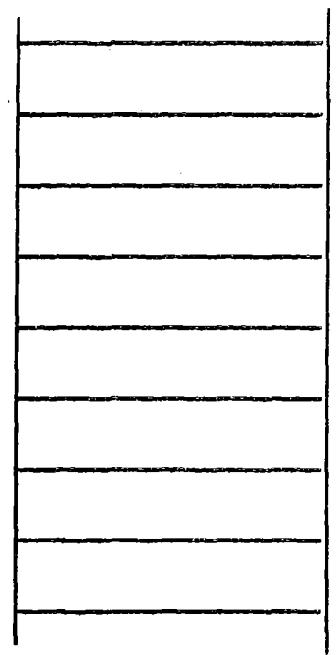

8. Have any of your close friends ever done any of these things?

Circle answer yes or no. If answer yes, circle answer how often:

Driven a motorcycle without a Yes No driver's license? If so, how often?

$0 \quad 1-2 \quad 3-9 \quad$ More than 9

Driven a car without a driver's Yes No

license? If so, how often? $\quad 0 \quad 1-2 \quad 3-9$. More than 9

Disobeyed their parents' Yes No authority (to their face)? If so, how often? $\quad 0 \quad 1-2 \quad 3-9 \quad$ More than 9

Taken little things that did not Yes No belong to them? If so, how often? $0 \quad 1-2 \quad 3-9 \quad$ More than 9

Bought or drunk beer, wine, Yes No or liquor (including drinking at home)? If so, how often?

$0 \quad 1-2 \quad 3-9 \quad$ More than 9

Run away from home? If so, Yes No how often?

$0 \quad 1-2 \quad 3-9 \quad$ More than 9

On purpose, damaged or de- Yes No stroyed things that did not belong to them? If so, how often? $0 \quad 1-2 \quad 3-9$ More than 9 
Number:

Date:

Place:

8. (continued)

Threatened another kid for money? If so, how often?

$\begin{array}{llll}\begin{array}{l}\text { Yes } \\ 0\end{array} \text { No }^{\text {No }} & 3-9 & \text { More than } 9 \\ \text { Yes } & \text { No } \\ 0 & 1-2 & 3-9 & \text { More than } 9\end{array}$

Beat up kids or adults who haven't done anything to them? If so, how often?

None one or two 21) do you know who have ever been in trouble with the police for other than a traffic violation? Circle answer.

three-five six-ten

More than ten

10. How many young people do you know (under 21) who have been taken to District or Juvenile Court?

None one or two

three-five six-ten

More than ten

11. Do you think that you might do any of these things in the future? If so, how often? Circle answer yes or no. If answer yes, circle how often.

Drive a motorcycle without a driver's license? If so, how often?

\begin{tabular}{llll} 
Yes & \multicolumn{2}{r}{ No } & \\
0 & $1-2$ & $3-9$ & More than 9 \\
Yes & No & & \\
0 & $1-2$ & $3-9$ & More than 9 \\
Yes & No & & \\
0 & $1-2$ & $3-9$ & More than 9 \\
Yes & No & & \\
0 & $1-2$ & $3-9$ & More than 9 \\
Yes & No & & \\
0 & $1-2$ & $3-9$ & More than 9
\end{tabular}

Drive a car without a driver's license? If so, how often?

Disobey your parents' authority (to their face)?. If so, how often?

Take little things that do not belong to you (worth less than $\$ 2.00)$ ? If so, how often?

Buy or drink beer, wine, or liquor (including drinking at home)? If so, how often? More than 9 
Number:

Date:

Place:

11. (continued)

Run away from home? If so, Yes No how often?

$0 \quad 1-2 \quad 3-9$. More than 9

On purpose, damage or

Yes No

destroy things that do not belong to you? If so, how often?

0 $\quad 1-2 \quad 3-9 \quad$ More than 9

Threaten another kid for money? If so, how often?

Yes No

$\begin{array}{llll}0 & 1-2 & 3-9 & \text { More than } 9\end{array}$

Beat up kids who hadn't done Yes No anything to you? If so, how often?

$0 \quad 1-2 \quad 3-9 \quad$ More than 9

12. Let's imagine for a moment that you have done each of these things. How likely do you think it would be that your parents would find out about it? Circle your answer.

$\begin{array}{llll}\text { Very Likely } \quad \text { Likely } & \text { Unlikely } \quad \text { Very Unlikely }\end{array}$

13. If you were to do these things, how likely do you think it would be that your neighbors would find out about it?
Very Likely
Likely
Unlikely
Very Unlikely

14. If you were to do these things, how likely do you think it would be that your friends would find out about it?
Very Likely
Likely
Unlikely
Very Unlikely

15. If you were to do these things, how likely do you think it would be that the police would catch you?
Very Likely
Likely
Unlikely
Very Unlikely

16. If your parents found out that you had done these things, how likely do you think it would be that they would punish you?
Very Likely
Likely
Unlikely
Very Unlikely 
Number:

Date:

Place:

17. If the police caught you doing these things, how likely do you think that they would have done anything about it?
Very Likely
Likely
Unlikely
Very Unlikely

18. If your neighbors found out that you had done these things, how likely do you think that they would have done anything about it?
Very Likely
Likely
Unlikely
Very Unlikely

19. If your friends found out that you had done these things, how likely do you think it is that they: would do anything about it?
Very Likely
Likely
Unlikely
Very Unlikely

20. Do you like the neighborhood you live in?

Very much Somewhat Not very much Not at all

21. How many of your close friends live in your neighborhood?

$$
0-3 \quad 4-7 \quad 8 \text { or more }
$$

22. How many of your close friends went to your school?

$$
0-3 \quad 4-7 \quad 8 \text { or more }
$$

23. How many of your close friends ran around together in a group?

$$
0-3 \quad 4-7 \quad 8 \text { or more }
$$

24. What kinds of activities did you usually participate in?

Club meetings or club activities?

Very frequently Quite often Sometimes Seldom Never

Dances or parties?

Very frequently, Quite often Sometimes Seldom Never

Church activities?

Very frequently Quite often Sometimes Seldom Never 
Number: Date: Place:

24. (continued)

Movies?

Very frequently Quite often Sometimes Seldom Never

Fishing-hunting?

Very frequently Quite often Sometimes Seldom Never

Picnics?

Very frequently Quite often Sometimes Seldom Never

Baseball?

Very frequently Quite often Sometimes Seldom Never

Basketball?

Very frequently Quite often Sometimes Seldom Never

Honda riding?

Very frequently Quite often Sometimes Seldom Never

Boating?

Very frequently Quite often Sometimes Seldom Never

Loafing?

Very frequently Quite often Sometimes Seldom Never

25. Who usually accompanied you to these activities? Put a check after the person who did any of the above things with you.

Father

Mother

Brother 
Number:

Date:

Place:

25. (continued) Sister

Other relative

Friends

Gal or Guy

Gang

No one

26. If you checked that you participated in the activity in question 24 at all, write in space after these questions one of the above persons or no one.

Who usually accompanied you to dances or parties?

Who usually went with you to church activities?

Who usually went with you to the movies?

Who usually went with you fishing or hunting?

Who usually went with you on picnics?

Who usually went with you to baseball?

Who usually went with you to basketball?

Who usually went Honda riding with you?

Who usually went boating with you?

Who usually loafed with you? 


\section{Significant Persons}

Respondent's

mother or mother person

father or father person

brother

sister

grandparents

police

correctional officers and counselors

school personnel

public welfare workers and homemaker

public health nurses

doctors

lawyers

ministers

business men

bus drivers

friends

gang members

mother's boy friend 